\title{
NEODIHYDROTHEBAINE AND BRACTAZONINE, TWO DIBENZ[d,f]AZONINE ALKALOIDS OF PAPAVER BRACTEATUM*
}

\author{
Hubert G. Theuns, Herman B. M. Lenting $\dagger$, Cornelis A. Salemink $\dagger$, Hitoshi Tanaka $\ddagger$, Masayoshi \\ Shibata $\ddagger$, Kazuo Ito $\ddagger$ and Robert J. J. Ch. LOUSBERg $§$
}

Laboratory of Organic Chemistry, Agricultural University, De Dreijen 5, 6703 BC Wageningen, The Netherlands; $\nmid$ Organic Chemical Laboratory, State University of Utrecht, Utrecht, The Netherlands; †Laboratory of Natural Products Chemistry, Faculty of Pharmacy, Meijo University, Nagoya, Japan; §Ministry of Welfare, Health and Culture, Leidschendam, The Netherlands

(Revised received 6 September 1983)

\begin{abstract}
Key Word Index-Papaver bracteatum; Papaveraceae; alkaloids; dibenz[d,f]azonines; neodihydrothebaine; bractazonine; biosynthetic pathway; synthesis; 5,6,8,9-tetrahydro-2-methoxy-7-methyl-dibenz[d,f]azonin-1,12diol; 5,6,8,9-tetrahydro-2,10-dimethoxy-7-methyl-dibenz[d,f]azonin-1-ol; 5,6,8,9-tetrahydro-2,11-dimethoxy-7methyl-dibenz[d,f]azonin-1-ol; 5,6,8,9-tetrahydro-2,12-dimethoxy-7-methyl-dibenz[d,f]azonin-1-ol.
\end{abstract}

\begin{abstract}
Two new dibenz[d,f]azonine alkaloids, neodihydrothebaine and bractazonine were isolated from Papaver bracteatum. Their possible biosynthesis from thebaine is discussed. The structures of both new alkaloids are proven by synthesis. An isomeric dibenz[d,f]azonine compound was also prepared.
\end{abstract}

\section{INTRODUCTION}

Several minor morphinane-type alkaloids were earlier reported to be present in Papaver bracteatum: codeine [1], neopine [1], the isomeric $N$-oxides of thebaine [2], oripavine [3], 14- $\beta$-hydroxycodeine [4], 14- $\beta$-hydroxycodeinone [4] and thebaine methochloride [5]. They can all be considered to be structurally derived from thebaine [6], the major alkaloid of this plant.

We now wish to report on the presence of two new alkaloids in $P$. bracteatum, both having a basic skeleton different from thebaine, but nevertheless probably biogenetically related to it. Neither of these two substances was earlier reported to occur in nature. One of them was identified as the synthetically derived compound $5,6,8,9$ tetrahydro-2,12-dimethoxy-7-methyl-dibenz [d,f]azonin1-ol (neodihydrothebaine, 1). The other one is hitherto unknown in literature, and we propose the name bractazonine for it. Bractazonine is shown to be isomeric to neodihydrothebaine, and is 5,6,8,9-tetrahydro-2,11dimethoxy-7-methyl-dibenz[d,f]azonin-1-ol, 2. Possible biosynthetic pathways for both new alkaloids are discussed. The structures of neodihydrothebaine and bractazonine are confirmed by synthesis. In doing so, another trisubstituted dibenz [d,f]azonine was prepared and its synthesis is also described. This is the first report on the natural occurrence of dibenz[d,f]azonine alkaloids within the Papaveraceae.

\section{RESULTS AND DISCUSSION}

Crude extracts of $P$. bracteatum were separated by counter-current fractionation [1]. GC/MS screening [4] revealed the presence of two $\mathrm{MW} \mathrm{m} / \mathrm{z}$ '313' alkaloids in fractions $99-127$. The mass spectrometrical fragmen-

\footnotetext{
* Part 6 in the Series; for part 5 see ref. [7].
}

tations of these two compounds showed strong resemblances to those reported for the naturally occurring Menispermaceae dibenz[d,f]azonine alkaloids laurifonine (3), laurifinine (4) and laurifine (5) $[8,9]$. Therefore, dibenz [d,f]azonine skeletons were assumed for the two alkaloids.

For further purification, subfractions 112-118 were submitted to preparative GC and TLC. Capillary GC/MS showed the isolated material to consist of a 1:1 mixture of the two unknown compounds. The ${ }^{1}$ H NMR spectrum of this mixture was fully compatible with the proposed dibenz $[d, f]$ azonine skeleton. Biogenetic considerations, as discussed below, suggested neodihydrothebaine (1) as a likely structure for one of the compounds. Therefore, neodihydrothebaine was prepared according to methods described in the literature $[10,11]$. Capillary GC/MS measurements provided evidence for the identity of synthetic neodihydrothebaine with one of the isolated compounds. For the unknown second alkaloid in the isolated mixture the name bractazonine is proposed.

Insight into the structure of bractazonine was obtained from its ${ }^{1}$ H NMR spectrum. Two methoxyl resonances at $\delta 3.90$ and 3.78 could be ascribed to neodihydrothebaine, whereas a second resonance at $\delta 3.90$ and one at 3.84 could be ascribed to bractazonine. The $N$-methyl signals of the two compounds at $\delta 2.28$ were barely separated from each other. All data suggested bractazonine to have an isomeric structure differing from 1 only in substitution pattern.

The location of the methoxyl groups in bractazonine was studied by ASIS-effects. In $\mathrm{CDCl}_{3}-\mathrm{C}_{6} \mathrm{D}_{6}(1: 1)$ the methoxyl resonances of synthetic 1 showed strong upfield shifts $(\delta 3.56$ and 3.53$)$. For the mixture of the natural alkaloids the same upfield shifts were observed for all methoxyl resonances. At this stage, it was convenient to know the chemical shift and ASIS-effect of a methoxyl located at position C-1. For this purpose, synthetic 1 was methylated. The newly introduced C-1 methoxyl was found at relatively high field $(\delta 3.54)$, most likely due to the 
experience of an anisotropy effect executed by the aromatic C-ring as a result of a twisting around the central bond of the biphenyl system. The ASIS-effect on this newly introduced methoxyl was virtually nil, whereas the two other methoxyl resonances of $O$-methylneodihydrothebaine (6) were affected to an equal extent as those in the parent compound 1 . These results strongly suggested that methoxyl substitution at $\mathrm{C}-1$ or $\mathrm{C}-13$ could be excluded for bractazonine $[12,13]$.

$\operatorname{Pr}(\text { fod })_{3}$ induced shifts in ${ }^{1}$ H NMR studies were expected to allow conclusive assignments of the position of methoxyl groups in the unknown alkaloid. As model substances 1,2-dimethoxybenzene and 2-methoxyphenol were studied first. The former compound showed large shifts of the methoxyl resonance upon addition of $\operatorname{Pr}(\mathrm{fod})_{3}$, and moderate line-broadening. For the latter substance, however, the induced shift of the methoxyl resonance was much smaller, and subject to considerable line broadening. The isolated methoxyl groups of 1,3dimethoxybenzene showed only small induced shifts in comparison to those of 1,2-dimethoxybenzene, while little line broadening occurred.

Clearly, the induced shifts of methoxyl resonances are dependent upon the aromatic substitution patterns: $o$ dimethoxy compounds experience large shifts; methoxyl resonances with a hydroxyl ortho to it show smaller shifts, accompanied with more distinct line broadening. Isolated methoxyl resonances exhibit negligible shifts and the line width remains virtually uninfluenced. The line broadening in the model compounds in the case of $o$-hydroxy methoxy substitution vs 0 -dimethoxy substitution was quite striking.

For neodihydrothebaine (1), the methoxyl resonance at low field shifted upon addition of small amounts of $\operatorname{Pr}(\text { fod })_{3}$ to higher field, with considerable line broadening (disappearance of wiggles, loss of height), while the other methoxyl resonance remained virtually unchanged. Completely in line with the above data from model compounds it can be concluded that the resonance found at lower field can be assigned to the methoxyl group at C-2. This result was further substantiated by the synthesis of compound 7 , which showed its $\mathrm{C}-2$ methoxyl resonance at $\delta 3.88$

The methoxyl group at C-12 ( $\delta 3.78)$ in $O$-methylneodihydrothebaine (6) remained virtually unchanged upon addition of $\operatorname{Pr}(\text { fod })_{3}$. The induced upfield shift of the C-1 methoxyl resonance was twice that of the C-2 methoxyl group. This result may be explained by the supposition that chelation takes place with the two oxygen atoms at C1 and $\mathrm{C}-2$, thus forcing the methyl protons of the methoxyl group at $\mathrm{C}-1$ in a steric position over ring $\mathrm{C}$. Protons in such a position experience the combined upfield shifts, caused by the shift reagent and by the anisotropy effect of ring $C$.

For laurifonine (3) synthesized from $\boldsymbol{O}$-methylflavinantine, the methoxyl resonances at $\delta 3.83$ and 3.91 shifted to higher field upon addition of the shift reagent, while the other methoxyl resonance at $\delta 3.78$ was virtually uninfluenced. Hence, the latter resonance in the ${ }^{1} \mathrm{H}$ NMR spectrum of laurifonine must be assigned to the $\mathrm{C}-12$ methoxyl group.

Laurifinine, which was earlier believed to have either structure 4 [8] or structure 8 [9], could be proven to be identical to compound 4 , by comparison with a synthetic reference sample [14]. The methoxyl resonance at $\delta 3.82$ in the ${ }^{1}$ H NMR spectrum of authentic laurifinine shifted upon addition of $\operatorname{Pr}(f \circ)_{3}$ to higher field, with considerable line broadening, while the other methoxyl group at $\delta 3.78$ remained almost uninfluenced. As a consequence the methoxyl at C-2 must be located at $\delta 3.82$.

For the isolated alkaloid mixture both methoxyl resonances at higher field remained virtually uninfluenced upon addition of $\operatorname{Pr}(\mathrm{fod})_{3}$. The coinciding methoxyl resonance at lower field (integrating for six protons) shifted to higher field, and slightly separated into two singlets, both with considerable line broadening. From these results bractazonine was considered to be a dibenz [d, f] azonine, possessing an isolated methoxyl group $(\delta 3.84)$ next to an $o$ hydroxy methoxyl function $(\delta 3.90)$.

Further examination of the chemical shifts of the isolated methoxyl groups in the compounds studied showed that the $\mathrm{C}-12$ methoxyl resonance was invariably found at $c a \delta 3.78$. Therefore a substitution pattern, which differs from those of the 1,2,12- and 2,3,12-trisubstituted compounds studied, should be considered for bractazonine.

The similarity of the natural alkaloids neodihydrothebaine and bractazonine in their chromatographic and extraction behaviours suggested an identical position of the phenolic function in these compounds. On the other hand, the different behaviour of the $o$-hydroxy methoxyl resonances in the $\operatorname{Pr}(\mathrm{fod})_{3}$ induced shift experiment on the isolated material suggested otherwise. The most likely substitution pattern of ring $\mathrm{C}$, from the biogenetic point of view, is a C-11 substitution for bractazonine (see below). Such considerations lead to the proposition of structure 2 for bractazonine. Although biogenetic considerations may provide useful indications for structural elucidations, they are not conclusive. Therefore it was necessary to prepare compound 9 as well. The need to compare bractazonine with the 10 -substituted product 9 was further stressed by the finding that the $\mathrm{C}-10$ methoxyl group of protostephanine (10) showed its resonance at $\delta 3.82$, as revealed by $\operatorname{Pr}(\mathrm{fod})_{3}$ induced shift studies in ${ }^{1}$ H NMR (see Experimental). For the synthesis of compounds 2 and 9 a photolytic cyclization procedure $[14,15]$ was employed.

In several chromatographic systems neodihydrothebaine (1), product 2 and product 9 showed identical $\boldsymbol{R}_{\boldsymbol{f}}$ values. In ${ }^{1} H$ NMR the synthetic compounds 2 and 9 were compared, each in $1: 1$ mixture with neodihydrothebaine, with the isolated natural mixture of alkaloids (see Experimental). Comparison of these data, with those obtained for the isolated mixture of natural alkaloids shows that the artificial mixture of products 1 and 2 is fully compatible with the data obtained for the isolated mixture of $P$. bracteatum alkaloids. The differences with the mixture of products 1 and 9 , however, are minimal, which stressed the need for further structural evidence. For this purpose GC/MS analysis was chosen.

In the mass spectra of 10 -methoxy-dibenz [d,f]azonine alkaloids a substantially more intense $[\mathrm{M}-\mathrm{OMe}]^{+}$ fragment ion was observed than in the spectra of 11methoxy- or 12-methoxy-dibenz [d,f]azonines. Both neocihydrothebaine and bractazonine showed no intense fragment ion at $m / z 282$. Consequently, structure 9 could be excluded as possible structure for bractazonine. These results indicated bractazonine to be identical with compound 2.

Next, the behaviour of the artificial mixture of neodihydrothebaine (1) and compound 2, tentatively identified as bractazonine, was studied in $\operatorname{Pr}(\mathrm{fod})_{3}$ shift experiment 
<smiles>COc1ccc(-c2c(CCN(C)C)ccc(OC)c2O)c(OC)c1</smiles>

I<smiles>[R7]CCc1ccc(OC)cc1-c1cc(OC)c(O[R7])cc1CCN[R7]</smiles>

$3 R^{1}=R^{2}=R^{3}=M e$

$4 R^{1}=H: R^{2}=R^{3}=M e$

$5 R^{1}=R^{2}=M e ; R^{3}=H$

$8 R^{1}=R^{3}=M e ; R^{2}=H$<smiles>COc1cc(OC)c(CCN(C)C)c(-c2cc(OC)c(OC)cc2CCN(C)C)c1</smiles>

10<smiles>COc1ccc(-c2c(CCN(C)C)ccc(OC)c2O)c(CCN(C)C)c1</smiles>

2<smiles>[R20]c1ccc(CCN(C)CCc2ccc(OC)c([R20])c2-c2cc([R20])ccc2OC)c([R])c1</smiles>

$6 \mathrm{R}^{1}=\mathrm{R}^{2}=\mathrm{Me}$

$7 R^{1}=R^{2}=H$<smiles>CCc1c(OC)cccc1-c1c(CCN(C)C)ccc(OC)c1O</smiles>

9<smiles>COc1cc(-c2cc(OC)c(OC)cc2CCN(C)C)c(CCN(C)C)cc1O</smiles>

11

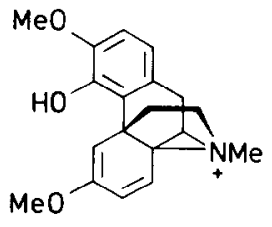

12 in ${ }^{1} \mathrm{H}$ NMR. The results, obtained for the latter mixture, were in full agreement with those, originally obtained from the isolated mixture of natural neodihydrothebaine and bractazonine. Obviously, there is some preference for the shift reagent to chelate with one of these alkaloids, thus causing the differences observed among the $o$ hydroxy methoxyl resonances. A capillary GC/MS comparison of the natural and synthetical mixtures of alkaloids confirmed their identity.

The possible formation of neodihydrothebaine (1) and bractazonine (2) as artifacts, resulting from acidic extraction conditions [16], can be excluded since both compounds were also detected in basic extracts.

The dibenz $[\mathrm{d}, \mathrm{f}]$ azonine skeleton is rarely encountered in nature. Apart from the three alkaloids laurifonine (3) laurifinine (4) and laurifine (5), isolated from the leaves of Cocculus laurifolius (Menispermaceae) $[8,9]$, only two other structurally related natural alkaloids have been found before: protostephanine (10) isolated from Stephania japonica (Menispermaceae) [17], and erybidine (11), in several Erythrina species (Leguminosae) [18-23]. The finding of the naturally occurring dibenz $[\mathrm{d}, \mathrm{f}]$ azonine alkaloids neodihydrothebaine (1) and bractazonine (2) in
$P$. bracteatum (Papaveraceae) adds two more representatives of this structural class to the small number of compounds already known.

The biosynthetic formation of 11- and 12-substituted dibenz [d,f]azonine alkaloids in $P$. bracteatum may be rationalized in terms of aryl and alkyl migrations, respectively, in the common precursor thebaine. These steps are also conceivable starting with salutaridinol, the immediate precursor of thebaine. The biosynthetic pathways, proposed here, are depicted in Scheme 1.

The pathway involving alkyl migration (pathway a), through the intermediary neospirinedienone methoxonium ion, is identical to the pathway followed in the synthesis of neodihydrothebaine from thebaine [10]. We now propose that the biosynthesis of 1 proceeds according to a similar route. The first step of pathway $b$ (Scheme 1) is analogous to some known reactions of morphinandienones $[24,25]$, whereas the conversion of proerythrinadienone intermediates into dibenz $[\mathrm{d}, \mathrm{f}] \mathrm{azo}$ nines, the next step in pathway $b$, was realized chemically [26], and is beyond question in the biosynthesis of Erythrina alkaloids [27]. A similar biosynthetic pathway, proceeding through an intermediary proerythrinadienol, 




Scheme 1. Proposed biosynthesis of dibenz[d,f]azonines in Papaver bracteatum.

was proposed for the in vivo formation of the dibenz $[\mathrm{d}, \mathrm{f}]$ azonine alkaloids laurifonine (3), laurifinine (4) and laurifine (5) [28]. The formation of a proerythrinadienone methoxonium ion, as proposed in pathway $b$, is likely to proceed through participation of the nitrogen lone pair, giving intermediate 12, in which stereoelectronic factors favour aryl migration [25].

In view of the finding of both neodihydrothebaine (1) and bractazonine (2) as natural alkaloids (most likely biogenetically derived from thebaine), it is imperative to refer to the classical exposé on the structural elucidation of thebaine, by R. Robinson [29]: "But the star performers in the team of molecular acrobats are undoubtedly the alkaloids of the morphine group and I shall speak especially of thebaine."

\section{EXPERIMENTAL}

GC/MS were recorded at $70 \mathrm{eV}$. Capillary GC/MS analyses were performed using a capillary CP Sil-5 (Chrompack) GC column ( $50 \mathrm{~m}$ glass; carrier gas $\mathrm{He} 5 \mathrm{ml} / \mathrm{min} ; 5 \mathrm{~min}$ isothermal at $200^{\circ}$, then $+4^{\circ} /$ min temp programmed to $300^{\circ}$ ) with an open split coupling (all glass system) linked to a double focussing mass spectrometer (electron impact, at $70 \mathrm{eV}$; source temperature $240^{\circ}$; cathode emission $0.7 \mathrm{~mA}$; acceleration voltage $800 \mathrm{~V}$; scan speed $1 \mathrm{decade} / \mathrm{min}$; interval $0.8 \mathrm{sec}$; mass range $22-520$ ), connected to a data system.
${ }^{1} \mathrm{HNMR}$ spectra were recorded in $\mathrm{CDCl}_{3}$ (unless given otherwise), at $90 \mathrm{MHz}$ in the CW mode or at $100 \mathrm{MHz}$ in the FT mode. TMS was int. standard $(\delta=0)$. ASIS-effects were studied by gradual addition of $\mathrm{C}_{6} \mathrm{D}_{6}$ to a $\mathrm{CDCl}_{3}$ soln of the alkaloid, until a ca 1:1 composition was reached. Shift expts were performed by addition of small vols of a soln of tris $(1,1,1,2,2,3,3$-heptafluoro7,7-dimethyl-4,6-octanedionato)praseodymium $\left[\operatorname{Pr}(\mathrm{fod})_{3}\right]$ in $\mathrm{CDCl}_{3}$ to a soln of the compounds in $\mathrm{CDCl}_{3}$, and recording spectra after each addition, until a ca $1: 10$ complex was reached. The resulting straight line graphs are expressed as normalized shielding gradients $\mathrm{d} \delta$ (calculated induced shifts in ppm for equimolar complexes). Differences in chemical shifts are given as $\Delta \delta$ in $\mathrm{ppm}$.

GC was carried out on a FID chromatograph using on-column injection and glass columns, packed with $3 \%$ OV-17 on Chrompack SA (80-100 mesh), operating at $260^{\circ}$ (system a), or with $3 \%$ SE-30 on Chromosorb W-HP (80-100 mesh), operating at $260^{\circ}$ (system b). For GC $R_{t}$ s thebaine was chosen as ref. ( $R R_{t}$ $\equiv 1.00$ ). TLC was performed on silica gel GF 254 plates using EtOAc-Et ${ }_{2} \mathrm{NH}(19: 1)$ (system a), or $\mathrm{C}_{6} \mathrm{H}_{6}-\mathrm{Me}_{2} \mathrm{CO}-\mathrm{MeOH}$ (7:2:1) (system b), or on $\mathrm{Al}_{2} \mathrm{O}_{3} \mathrm{~F} 254$ (type E) plates using $\mathrm{CHCl}_{3}$-heptane- $\mathrm{Et}_{2} \mathrm{O}(4: 5: 1)$ (system c). Alkaloid detection was accomplished using UV light ( $254 \mathrm{~nm}$ ). Mps are corr.

Plant extraction and concentration of alkaloids. (i) Capsules of P. bracteatum Lindl, cv 'Arya I', cultivated by Franco-Pavot Industries, France, were extracted as reported earlier [1]. The concn of neodihydrothebaine plus bractazonine $(1+2)$ in the 
crude extract was $0.036 \%$ dry wt. (ii) Capsules of $P$. bracteatum, cv 'Arya II', cultivated at the Agricultural University Wageningen, Wageningen, The Netherlands, were extracted by elution using $5 \%$ aq. HOAc for $2 \mathrm{hr}$, and after adjustment of the $\mathrm{pH}$ of the eluate to 8.9 using an $\mathrm{NH}_{3}-\mathrm{NH}_{4} \mathrm{Cl}$ buffer soln, extracted with $\mathrm{CHCl}_{3}-i$ so-PrOH $(3: 1)$. Solvents were removed in vacuo at low temp and the residue analysed by GC. The concn of thebaine was $2.66 \%$ and the concn of $(1+2)$ was $0.11 \%$ dry wt. In the non-phenolic alkaloid fraction of an $\left(\mathrm{H}_{2} \mathrm{O}-\mathrm{K}_{2} \mathrm{CO}_{3}-n\right.$ $\mathrm{BuOH}-\mathrm{C}_{6} \mathrm{H}_{6}$ ) extract of the same plant material, the presence of $(1+2)$ was demonstrated.

Isolation of a mixture of neodihydrothebaine (1) and bractazonine (2). Counter-current fractions 112-118 [1] were submitted to prep. GC $\left(3 \% \mathrm{OV}-17,270^{\circ}\right)$, yielding $3.1 \mathrm{mg}$ of material, homogeneous by TLC. In order to remove some starting point material in TLC, this material was submitted to prep. TLC (system a), yielding $1.7 \mathrm{mg}$ of a $1: 1$ mixture of neodihydrothebaine and bractazonine. ${ }^{1} \mathrm{H}$ NMR: $\delta 2.28(6 \mathrm{H}, 2 \times \mathrm{s}, 2$ $\times \mathrm{NMe}), 2.3-2.7\left(16 \mathrm{H}, m, 8 \times \mathrm{CH}_{2}\right), 3.78(3 \mathrm{H}, s, \mathrm{OMe}), 3.84(3 \mathrm{H}$, $s$, OMe), $3.90(6 \mathrm{H}, s, 2 \times \mathrm{OMe}), 6.7-7.2(10 \mathrm{H}, m$, aromatic $\mathrm{H})$. Accurately determined $\delta$ values of the OMe resonances in ${ }^{1} \mathrm{H}$ NMR of the natural mixture (using FT-NMR) were $\delta 3.780$, 3.837 and 3.904. In $\mathrm{CDCl}_{3}-\mathrm{C}_{6} \mathrm{D}_{6}(1: 1)$ the $\mathrm{OMe}$ resonances were found at $\delta 3.50-3.56$. The normalized shielding gradients in a $\operatorname{Pr}$ (fod) $)_{3}$ shift expt were for $\delta 2.28 \mathrm{~d} \delta 4.3$ and 5.1 , for $\delta 3.78 \mathrm{~d} \delta 0.5$, for $\delta 3.84 \mathrm{~d} \delta 0.7$, and for $\delta 3.90 \mathrm{~d} \delta 12$ and 16 .

$\operatorname{Pr}(\mathrm{fod})_{3}$ shift experiments on model compounds. The normalized shielding gradients were for 1,2-dimethoxybenzene $\mathrm{d} \delta 30$, for 2-methoxyphenol $\mathrm{d} \delta 9.3$, and for 1,3-dimethoxybenzene $\mathrm{d} \delta 0.20$.

$\operatorname{Pr}(\text { fod })_{3}$ shift experiments on alkaloids 1, 3, 4, 6 and 10. Neodihydrothebaine (1): $\delta 2.28$ (NMe) d $7.9, \delta 3.78$ (C-12 OMe) $\mathrm{d} \delta 0.6, \delta 3.90$ (C-2 OMe) d $\delta 14$; Laurifonine (3): $\delta 2.31$ (NMe) $\mathrm{d} \delta 3.8, \delta 3.78$ (C-12 OMe) d $\delta 0.7, \delta 3.83$ (C-2 OMe) d $\delta 19, \delta 3.91$ (C-3 OMe) d $\delta 20$; Laurifinine (4): $\delta 2.32$ (NMe)d $\delta 1.4, \delta 3.78$ (C-12 $\mathrm{OMe}) \mathrm{d} \delta \sim 0, \delta 3.82$ (C-2 OMe) d $\delta 2.6$; O-Methylneodihydrothebaine (6): $\delta 2.28$ (NMe) d $\delta 4.7, \delta 3.54$ (C-1 OMe) d $\delta 7.3, \delta 3.78$ (C-12 OMe) d $\delta 0.2, \delta 3.89$ (C-2 OMe) d $\delta 4.0 ;$ Protostephanine (10): $\delta 2.30(\mathrm{NMe}) \mathrm{d} \delta 4.7, \delta 3.78(\mathrm{C}-12 \mathrm{OMe}) \mathrm{d} \delta 0.8, \delta 3.82 \mathrm{~d} \delta 1.2(\mathrm{C}-10$ $\mathrm{OMe})$ and 15 (C-2 OMe), $\delta 3.91$ (C-3 OMe) $\mathrm{d} \delta 16$.

Laurifinine (4). ${ }^{1} \mathrm{H}$ NMR: $\delta 2.32(3 \mathrm{H}, \mathrm{s}, \mathrm{NMe}), 2.3-2.8(8 \mathrm{H}, \mathrm{m}$, $\left.4 \times \mathrm{CH}_{2}\right), 3.78(3 \mathrm{H}, s, \mathrm{OMe}), 3.82(3 \mathrm{H}, s, \mathrm{OMe}), 5.0(1 \mathrm{H}$, br $s, \mathrm{OH})$, 6.67 and $6.80(2 \mathrm{H}, 2 \times s, \mathrm{H}-1$ and $\mathrm{H}-4), 6.72(1 \mathrm{H}, d, J=2.7 \mathrm{~Hz}, \mathrm{H}-$ 13), $6.87(1 \mathrm{H}, d d, J=2.7$ and $8.4 \mathrm{~Hz}, \mathrm{H}-11), 7.15(1 \mathrm{H}, d, J$ $=8.4 \mathrm{~Hz}, \mathrm{H}-10)$. The $\Delta \delta(\mathrm{OMe})$ observed was 0.041 . In $\mathrm{CDCl}_{3}-\mathrm{C}_{6} \mathrm{D}_{6}(1: 1)$ the $\mathrm{OMe}$ resonances were found at $\delta 3.42$ and 3.54. GC/MS $m / z$ (rel. int.): 314 (23), 313 (100), 312 (14), 311 (23), 298 (15), 270 (10), 257 (26), 256 (71), 255 (71), 239 (14), 226 (10), 225 (40), 195 (12).

Protostephanine (10). ${ }^{1} \mathrm{H}$ NMR: $\delta 2.30(3 \mathrm{H}, s, \mathrm{NMe}), 2.0-3.0$ $\left(8 \mathrm{H}, m, 4 \times \mathrm{CH}_{2}\right), 3.78(3 \mathrm{H}, s, \mathrm{OMe}), 3.82(6 \mathrm{H}, s, 2 \times \mathrm{OMe}), 3.91$ $(3 \mathrm{H}, s, \mathrm{OMe}), 6.32$ and $6.45(2 \mathrm{H}, 2 \times d, J=2.4 \mathrm{~Hz}, \mathrm{H}-11$ and $\mathrm{H}$ 13), 6.66 and $6.73(2 \mathrm{H}, 2 \times s, \mathrm{H}-1$ and $\mathrm{H}-4)$. The observed $\Delta \delta$ (OMe) were 0.042, 0.087 and 0.128. GC/MS m/z (rel. int.): 358 (23), 357 (100), 355 (19), 342 (12), 326 (16), 313 (13), 302 (16), 301 (91), 300 (82), 299 (88), 283 (11), 270 (14), 269 (12), 268 (11), 255 (11).

Synthesis of 1 from thebaine. Method a. This synthesis was accomplished starting from thebaine $(4.4 \mathrm{~g})$, using freshly prepared $\mathrm{MgI}_{2}$, and subsequent reduction of the resulting imine by the action of $\mathrm{LiAlH}_{4}$, as recorded in ref. [10]. Florisil chromatography (eluent $\mathrm{Et}_{2} \mathrm{O}$ ) yielded a yellow solid, which was further purified by prep. TLC (system a). Yield $57 \%$ Mp $100^{\circ}$ (from $\mathrm{MeOH})$. Method $b$. Thebaine $(1.08 \mathrm{~g})$ was dissolved in TFA $(5 \mathrm{ml})$ [11]. The dark-red soln discoloured quickly, and after stirring for $0.5 \mathrm{hr}$ at room temp the pink soln was evaporated in vacuo.
$\mathrm{MeOH}(60 \mathrm{ml})$ was added to the yellow syrup, and $\mathrm{NaBH}_{4}$ (large excess) was added portionwise. The reaction mixture was stirred for $0.5 \mathrm{hr}$ and, after addition of $\mathrm{H}_{2} \mathrm{O}$, concd in vacuo. $\mathrm{CHCl}_{3}$ extraction was performed and the extract dried over $\mathrm{Na}_{2} \mathrm{SO}_{4}$. After evaporation of solvent, the residue was chromatographed on an $\mathrm{Al}_{2} \mathrm{O}_{3}$ column (activity III, $\mathrm{CHCl}_{3}$ satd with $\mathrm{H}_{2} \mathrm{O}$ ), affording pure $1\left(1.03 \mathrm{~g}\right.$; yield $\left.95^{\circ} \%\right)$. Mp $107^{\circ} .{ }^{1} \mathrm{H}$ NMR: $\delta 2.28$ (3H, $s, \mathrm{NMe}), 2.3-2.7\left(8 \mathrm{H}, m, 4 \times \mathrm{CH}_{2}\right), 3.78(3 \mathrm{H}, s, \mathrm{OMe}), 3.90$ (3H, s, OMe), $5.08(1 \mathrm{H}$, br $s, \mathrm{OH}), 6.73$ and $6.84(2 \mathrm{H}, \mathrm{AB}$-pattern, $J=8.1 \mathrm{~Hz}, \mathrm{H}-3$ and $\mathrm{H}-4), 6.74,6.90$ and $7.18(3 \mathrm{H}, \mathrm{ABC}$-pattern, $J_{10.11}=8.3 \mathrm{~Hz}, J_{11.13}=2.7 \mathrm{~Hz}, \mathrm{H}-13, \mathrm{H}-11$ and $\mathrm{H}-10$, respectively). The $\Delta \delta(\mathrm{OMe})$ was determined as 0.125 . In $\mathrm{CDCl}_{3}-\mathrm{C}_{6} \mathrm{D}_{6}$ $(1: 1)$ the $\mathrm{OMe}$ resonances were found at $\delta 3.53$ and 3.56 . GC/MS $m / z$ (rel. int.): 314 (22), 313 (100), 312 (11), 298 (11), 296 (16), 270 (14), 257 (30), 256 (66), 255 (48), 239 (10), 225 (17), 223 (26), 195 (11).

Synthesis of O-methylneodihydrothebaine (6). Compound 1 $\left(50 \mathrm{mg}\right.$ ) was treated with excess $\mathrm{CH}_{2} \mathrm{~N}_{2}$ in $\mathrm{Et}_{2} \mathrm{O}$ for 3 days at room temp. Evaporation of solvent gave the $O$-Me ether. This product was purified by TLC (system a). Yield $83 \%$. Oil. ${ }^{1} \mathrm{H}$ NMR: $\delta 2.26(3 \mathrm{H}, s, \mathrm{NMe}), 2.3-2.7\left(8 \mathrm{H}, m, 4 \times \mathrm{CH}_{2}\right), 3.54(3 \mathrm{H}$, $s, \mathrm{OMe}), 3.78$ (3H, $s, \mathrm{OMc}), 3.89$ (3H, $s, \mathrm{OMc}), 6.90$ (2H, A2pattern, $J=8.7 \mathrm{~Hz}, \mathrm{H}-3$ and $\mathrm{H}-4), 6.68,6.85$ and $7.13(3 \mathrm{H}, \mathrm{ABC}$ pattern, $J_{10,11}=8.4 \mathrm{~Hz}, J_{11,13}=2.7 \mathrm{~Hz}, \mathrm{H}-13, \mathrm{H}-11$ and $\mathrm{H}-10$, respectively). In $\mathrm{CDCl}_{3}-\mathrm{C}_{6} \mathrm{D}_{6}(1: 1)$ the $\mathrm{OMe}$ resonances were found at $\delta 3.48,3.50$ and 3.61. GC/MS $m / z$ (rel. int.): 328 (22), 327 (100), 326 (10), 325 (15), 297 (11), 296 (54), 271 (36), 270 (40), 269 (21), 256 (10), 255 (15), 254 (25), 253 (71), 240 (14), 239 (28), 238 (30), 225 (12), $165(13), 152(10)$.

Synthesis of 5,6,8,9-tetrahydro-2-methoxy-7-methyl-dibenz$[d, f]$ azonin-1,12-diol (7). Thebaine. $\mathrm{HCl}(1.08 \mathrm{~g})$ was dissolved in TFA ( $5 \mathrm{ml})$ and stirred at room temp for $0.5 \mathrm{hr}$. The soln retained its red colour. The TFA was removed in vacuo, $\mathrm{MeOH}(20 \mathrm{ml})$ and $\mathrm{NaBH}_{4}$ (large excess) was added to the yellow residue and the reaction mixture stirred for $0.5 \mathrm{hr}$ at room temp. $\mathrm{H}_{2} \mathrm{O}$ was added and the $\mathrm{MeOH}$ removed in vacuo. $\mathrm{CHCl}_{3}$ extraction, drying over $\mathrm{MgSO}_{4}$ and concn afforded the crude product $(1.02 \mathrm{~g})$. This was separated on $\mathrm{Al}_{2} \mathrm{O}_{3}$ (activity III). Elution with hexane- $\mathrm{Et}_{2} \mathrm{O}$ (1:1) and $\mathrm{CHCl}_{3}-\mathrm{Et}_{2} \mathrm{O}$ mixtures afforded first fractions, which on further purification were shown to contain $1(10 \mathrm{mg}$, yield $1 \%)$, neopine $(169 \mathrm{mg}$, yield $18 \%)$, isoneopine $(150 \mathrm{mg}$, yield $16 \%)$ and codeine (10 mg, yield $1 \%$ ). Finally compound 7 was eluted (oil, $233 \mathrm{mg}$, yield $25 \%$ ). ${ }^{1} \mathrm{H}$ NMR: $\delta 2.24$ (3H, $s, \mathrm{NMe}$ ), 2.2-2.8 $\left(8 \mathrm{H}, \mathrm{m}, 4 \times \mathrm{CH}_{2}\right), 3.88$ (3H, s, OMe), $5.6(2 \mathrm{H}, b r s, 2 \times \mathrm{OH}), 6.58$ $(1 \mathrm{H}, d, J=2.7 \mathrm{~Hz}, \mathrm{H}-13), 6.72$ and $6.82(2 \mathrm{H}$, AB-pattern, $J$ $=8.4 \mathrm{~Hz}, \mathrm{H}-3$ and $\mathrm{H}-4), 6.73(1 \mathrm{H}, d d, J=2.7 \mathrm{~Hz}, J=8.4 \mathrm{~Hz}, \mathrm{H}-$ 11), $7.10(1 \mathrm{H}, d, J=8.4 \mathrm{~Hz}, \mathrm{H}-10)$. GC/MS $m / z$ (rel. int.): 300 (20), 299 (100), 298 (12), 284 (10), 282 (18), 256 (14), 243 (19), 242 (44), 241 (42), 225 (10), 211 (16), 209 (30), 181 (15).

Synthesis of laurifonine 3 from O-methylfavinantine. This synthesis was performed in an analogous manner to that of protostephanine from protostephanone [30,31]. O-Methylflavinantine $(13,299 \mathrm{mg})$ was stirred with excess $\mathrm{NaBH}_{4}(430 \mathrm{mg})$ in $\mathrm{MeOH}\left(30 \mathrm{ml}\right.$ ) for $4 \mathrm{hr}$ at $0^{\circ}$. The reaction was monitored by TLC (silica gel $\mathrm{C}_{6} \mathrm{H}_{6}-\mathrm{EtOAc}-\mathrm{Et}_{2} \mathrm{NH}(7: 2: 1) R_{f} \quad 130.44 ; R_{f} O$ methylfavinantinol-I (14) $0.37 ; R_{f} O$-methylflavinantinol-II (15) 0.23 -detection by conc $\mathrm{H}_{2} \mathrm{SO}_{4}$ spray, giving bright orange spots for the dienols). Upon addition of $\mathrm{H}_{2} \mathrm{O}(30 \mathrm{ml})$ the $\mathrm{MeOH}$ was removed in vacuo at room temp and the products extracted into $\mathrm{CH}_{2} \mathrm{Cl}_{2}(6 \times 30 \mathrm{ml})$. The soln was dricd $\left(\mathrm{Na}_{2} \mathrm{SO}_{4}\right)$ and evaporated, yield $238 \mathrm{mg}$. The intermediary dienols were isolated in one prepn using the above TLC system.

O-Methylfavinantinol-I (14). ${ }^{1} \mathrm{H}$ NMR: $\delta 2.47(3 \mathrm{H}, \mathrm{s}, \mathrm{NMe})$, $3.74(3 \mathrm{H}, s, \mathrm{OMe}), 3.85(3 \mathrm{H}, s, \mathrm{OMe}), 3.88(3 \mathrm{H}, s, \mathrm{OMe}), 4.70(1 \mathrm{H}$, $d, J=3.9 \mathrm{~Hz}, \mathrm{H}-7), 5.32(1 \mathrm{H}, s, \mathrm{H}-5), 5.81(1 \mathrm{H}, d, J=3.9 \mathrm{~Hz}, \mathrm{H}-$ $8), 6.59(1 \mathrm{H}, \mathrm{s}, \mathrm{H}-1), 6.79(1 \mathrm{H}, \mathrm{s}, \mathrm{H}-4)[32]$. 
O-Methylfavinantinol-II (15). ' $\mathrm{H}$ NMR: $\delta 2.47(3 \mathrm{H}, s, \mathrm{NMe})$, 3.74 (3H, s, OMe), 3.85 (3H, s, OMe), 3.88 (3H, s, OMe), $4.56(1 \mathrm{H}$, $d, J=3.1 \mathrm{~Hz}, \mathrm{H}-7), 5.30(1 \mathrm{H}, s, \mathrm{H}-5), 5.76(1 \mathrm{H}, d, J=3.1 \mathrm{~Hz}, \mathrm{H}-8)$, $6.60(1 \mathrm{H}, s, \mathrm{H}-1), 6.77(1 \mathrm{H}, s, \mathrm{H}-4)$ [32]. The above dienols 14 and $15(238 \mathrm{mg})$ were stirred for $18 \mathrm{hr}$ in TFA $(20 \mathrm{ml})$ under $\mathrm{N}_{2}$, giving instantaneously a red colour. The TFA was removed in vacuo and the residue in $\mathrm{MeOH}$ was treated portionwise with excess $\mathrm{NaBH}_{4}$ at $\mathrm{O}^{\circ}$. After stirring for $2 \mathrm{hr}, \mathrm{H}_{2} \mathrm{O}$ was added, and the $\mathrm{MeOH}$ removed in vacuo. Extraction into $\mathrm{CH}_{2} \mathrm{Cl}_{2}$ yielded after drying ( $\mathrm{Na}_{2} \mathrm{SO}_{4}$ ) upon evaporation compound 3 (oil, $209 \mathrm{mg}$, yield $73 \%$ ). ${ }^{1} \mathrm{H}$ NMR: $\delta 2.31$ (3H, $\left.s, \mathrm{NMe}\right), 2.4-2.8(8 \mathrm{H}$, $m, 4 \times \mathrm{CH}_{2}$ ), 3.78 (3H, $s, \mathrm{OMe}$ ), 3.83 (3H, $s, \mathrm{OMe}$ ), 3.91 (3H, $s$, $\mathrm{OMe}), 6.68$ and $6.73(2 \mathrm{H}, 2 \times s, \mathrm{H}-1$ and $\mathrm{H}-4), 6.72(1 \mathrm{H}, d, J$ $=2.7 \mathrm{~Hz}, \mathrm{H}-13), 6.86(1 \mathrm{H}, d d, J=2.7 \mathrm{~Hz}, J=8.4 \mathrm{~Hz}, \mathrm{H}-11), 7.14$ (1H, $d, J=8.4 \mathrm{~Hz}, \mathrm{H}-10$ ). GC/MS $m / z$ (rel. int.): 328 (23), 327 (100), 312 (17), 284 (13), 271 (58), 270 (79), 269 (69), 254 (12), 253 (16), 240 (18), 239 (11), 238 (15), 165 (13), 152 (11).

Total synthesis of 2 . Bractazonine was synthesized using a procedure involving a photolytic aryl coupling reaction $[14,15]$. The substrate for this photolytic reaction was prepared from 2-bromo-3-hydroxy-4-methoxybenzaldehyde and 3-hydroxybenzaldehyde.

2-Bromo-3-isopropoxy-4-methoxybenzaldehyde (16). 2-Bromo3-hydroxy-4-methoxybenzaldehyde [33] (0.05 mole) and dry $\mathrm{K}_{2} \mathrm{CO}_{3}(3.8 \mathrm{~g})$ in dry DMF $(50 \mathrm{ml})$ were stirred in an $\mathbf{N}_{2}$ atmosphere, while 2-bromopropane $(0.06 \mathrm{~mole})$ was added dropwise in $15 \mathrm{~min}$. After another $30 \mathrm{~min}$ stirring at room temp, the reaction mixture was heated at $100^{\circ}$ for $2 \mathrm{hr}$. After cooling, the reaction mixture was poured on ice- $\mathrm{H}_{2} \mathrm{O}(250 \mathrm{~g})$ and extracted with $\mathrm{Et}_{2} \mathrm{O}(4 \times 300 \mathrm{ml})$. The extract was washed with $\mathrm{H}_{2} \mathrm{O}$ $(50 \mathrm{ml})$, dried $\left(\mathrm{MgSO}_{4}\right)$, and concd in vacuo giving product 16 in $91 \%$ yield. Mp 48 ${ }^{1} \mathrm{H}$ NMR: $\delta 1.33\left(6 \mathrm{H}, d, J=6 \mathrm{~Hz}, \mathrm{CMe}_{2}\right)$, $3.93(3 \mathrm{H}, s, \mathrm{OMe}), 4.61\left(1 \mathrm{H}, m, J=6 \mathrm{~Hz}, \mathrm{CHMe}_{2}\right), 6.96$ and 7.72 $(2 \mathrm{H}, 2 \times d, J=8.6 \mathrm{~Hz}, \mathrm{H}-5$ and $\mathrm{H}-6), 10.32(1 \mathrm{H}, s, \mathrm{CHO})$. GC/MS m/z (rel. int.): 274 (9), 272 (9), 233 (9), 232 (94), 231 (75), $230(100), 229(69)$.

2-Bromo-3-isopropoxy-4-methoxybenzylalcohol (17). Compound 16 in EtOH was treated portionwise with $\mathrm{NaBH}_{4}(1.2$ equivalent). After stirring for $1 \mathrm{hr}, \mathrm{H}_{2} \mathrm{O}$ was added and the $\mathrm{EtOH}$ removed in vacuo. After acidification using conc $\mathrm{HCl}, \mathrm{CHCl}_{3}$ extraction was performed. The extract was washed with $\mathrm{H}_{2} \mathrm{O}$, aq. $\mathrm{HCl}(3 \mathrm{~N})$ and $\mathrm{H}_{2} \mathrm{O}$, dried $\left(\mathrm{MgSO}_{4}\right)$ and concd in vacuo. Yield $100 \%$. Oil. ${ }^{1} \mathrm{H}$ NMR: $\delta 1.32\left(6 \mathrm{H}, d, J=6 \mathrm{~Hz}, \mathrm{CMe}_{2}\right), 2.23(1 \mathrm{H}, b r$ $s, \mathrm{OH}), 3.85(3 \mathrm{H}, s, \mathrm{OMe}), 4.59\left(1 \mathrm{H}, m, J=6 \mathrm{~Hz}, \mathrm{CHMe}_{2}\right), 4.70$ $\left(2 \mathrm{H}, \mathrm{s}, \mathrm{ArCH}_{2} \mathrm{O}\right), 6.84$ and $7.14(2 \mathrm{H}, 2 \times d, J=8 \mathrm{~Hz}, \mathrm{H}-5$ and $\mathrm{H}-$ 6). GC/MS m/z (rel. int.): 276 (20), 274 (20), 234 (95), 233 (18), 232 (100), 231 (11), 217 (15), 215 (15), 153 (31), 125 (24), 124 (29), 110 (16).

2-Bromo-3-isopropoxy-4-methoxybenzylchloride (18). Compound $17(38 \mathrm{~g})$ in dry $\mathrm{Et}_{2} \mathrm{O}(380 \mathrm{ml})$ and pyridine $(1.4 \mathrm{ml})$ was treated with $\mathrm{SOCl}_{2}(27 \mathrm{ml})$ in dry $\mathrm{Et}_{2} \mathrm{O}(90 \mathrm{ml})$. The reaction mixture was stirred at room temp for $20 \mathrm{~min}$. The soln was washed with $\mathrm{H}_{2} \mathrm{O}(2 \times 150 \mathrm{ml})$ and with dil. aq. $\mathrm{NH}_{3}$ and dried $\left(\mathrm{MgSO}_{4}\right)$. Evaporation of solvent gave $18(39 \mathrm{~g}$, yield $96 \%)$. Oil. ${ }^{1} \mathrm{H} \mathrm{NMR:} \delta 1.31\left(6 \mathrm{H}, d, J=6 \mathrm{~Hz}, \mathrm{CMe}_{2}\right), 3.83(3 \mathrm{H}, s, \mathrm{OMe}), 4.58$ $\left(1 \mathrm{H}, m, J=6 \mathrm{~Hz}, \mathrm{CHMe}_{2}\right), 4.70\left(2 \mathrm{H}, \mathrm{s}, \mathrm{ArCH}_{2} \mathrm{Cl}\right), 6.84$ and 7.18 (2H, $2 \times d, J=8$ Hz, H-5 and H-6). GC/MS $m / z$ (rel. int.): 296 (3), 294 (14), 292 (10), 259 (3), 257 (3), 254 (11), 253 (4), 252 (45), 251 (4), 250 (35), 218 (8), 217 (97), 216 (9), 215 (100), 202 (4), 200 (4).

2-Bromo-3-isopropoxy-4-methoxybenzylcyanide (19). KCN $(10.7 \mathrm{~g})$ was added to $18(39 \mathrm{~g})$ in DMSO $(250 \mathrm{ml})$ and stirred at room temp for $18 \mathrm{hr}$. The reaction mixture was poured into $\mathrm{H}_{2} \mathrm{O}$ (1.5 l.) and extraction with $\mathrm{Et}_{2} \mathrm{O}(5 \times 400 \mathrm{ml})$ was performed. The $\mathrm{Et}_{2} \mathrm{O}$ extracts were washed with brine $(2 \times 150 \mathrm{ml})$, dried $\left(\mathrm{MgSO}_{4}\right)$ and concd in vacuo. Yield $36 \mathrm{~g}(95 \%)$. Mp $45^{\circ}$. ${ }^{1} \mathrm{H}$ NMR: $\delta 1.31\left(6 \mathrm{H}, d, J=6 \mathrm{~Hz}, \mathrm{CMe}_{2}\right), 3.79(2 \mathrm{H}, s$,
$\left.\mathrm{ArCH}_{2} \mathrm{CN}\right), 3.86(3 \mathrm{H}, s, \mathrm{OMe}), 4.60\left(1 \mathrm{H}, m, J=6 \mathrm{~Hz}, \mathrm{CHMe}_{2}\right)$ 6.86 and $7.22(2 \mathrm{H}, 2 \times d, J=9 \mathrm{~Hz}, \mathrm{H}-5$ and H-6). GC/MS $\mathrm{m} / \mathrm{z}$ (rel. int.): 285 (7), 283 (8), 244 (10), 243 (99), 242 (12), 241 (100), 228 (17), $226(18), 162$ (27).

2-Bromo-3-isopropoxy-4-methoxyphenylacetic acid (20). Compound $19(0.4 \mathrm{~mol})$, ethylene glycol $(500 \mathrm{ml})$ and $\mathrm{KOH}(100 \mathrm{~g})$ in $\mathrm{H}_{2} \mathrm{O}(150 \mathrm{ml})$ were refluxed for $2 \mathrm{hr}$. The reaction mixture was poured into $\mathrm{H}_{2} \mathrm{O}(21$.) and extracted with EtOAc $(3 \times 300 \mathrm{ml})$. The aq. phase was acidified $(6 \mathrm{~N} \mathrm{HCl})$ and extracted with $\mathrm{CHCl}_{3}$ $(4 \times 500 \mathrm{ml})$. The extracts were dried $\left(\mathrm{MgSO}_{4}\right)$ and the solvent removed in vacuo. Yield 90\%. Mp 99 ${ }^{\circ}{ }^{1} \mathrm{H}$ NMR: $\delta 1.31(6 \mathrm{H}, d, J$ $\left.=6 \mathrm{~Hz}, \mathrm{CMe}_{2}\right), 3.78\left(2 \mathrm{H}, s, \mathrm{ArCH}_{2} \mathrm{COOH}\right), 3.82$ (3H, $\left.s, \mathrm{OMe}\right)$, $4.57\left(1 \mathrm{H}, m, J=6 \mathrm{~Hz}, \mathrm{CHMe}{ }_{2}\right), 6.79$ and $6.97(2 \mathrm{H}, \mathrm{AB}$-pattern, $J$ $=8.5 \mathrm{~Hz}, \mathrm{H}-5$ and $\mathrm{H}-6$, respectively), $9.90(1 \mathrm{H}, b r s, \mathrm{COOH})$. GC/MS $m / z$ (rel. int.): 304 (25), 302 (25), 263 (8), 262 (66), 261 (8), 260 (67), 218 (9), 217 (98), 216 (10), 215 (100), 182 (9), 181 (64), 137 (9).

3-Tosyloxybenzaldehyde (21). 3-Hydroxybenzaldehyde (20 g) was stirred with tosylchloride (1 equivalent) in pyridine $(225 \mathrm{ml})$ for $18 \mathrm{hr}$. The solvent was removed in vacuo and the residue divided between $\mathrm{H}_{2} \mathrm{O}(250 \mathrm{ml})$ and $\mathrm{CHCl}_{3}(4 \times 300 \mathrm{ml})$. The extracts were washed with $\mathrm{H}_{2} \mathrm{O}(100 \mathrm{ml}), 3 \mathrm{~N} \mathrm{HCl}(100 \mathrm{ml})$ and $\mathrm{H}_{2} \mathrm{O}(100 \mathrm{ml})$. After drying over $\mathrm{MgSO}_{4}$ the solvent was removed in vacuo, giving compound $21(42 \mathrm{~g}$, yield $92 \%) . \mathrm{Mp} 63^{\circ}$. ${ }^{1} \mathrm{H}$ NMR: $\delta 2.44$ (3H, $\left.s, \mathrm{ArMe}\right), 7.2-7.9$ (8H, $\left.m, \mathrm{ArH}\right), 9.96(1 \mathrm{H}, \mathrm{s}$, CHO). GC/MS $m / z$ (rel. int.): 276 (14), 155 (47), 92 (9), 91 (100).

3-Tosyloxybenzylalcohol (22). To compound $21(41.6 \mathrm{~g})$ in cold dry THF (750 ml), $\mathrm{NaBH}_{4}(17.1 \mathrm{~g})$ was added. In an $\mathrm{N}_{2}$ atmosphere $\mathrm{BF}_{3} \cdot \mathrm{OEt}_{2}(76.1 \mathrm{ml})$ in dry THF $(100 \mathrm{ml})$ was added dropwise in $1 \mathrm{hr}$ at $0^{\circ}$. After stirring for $15 \mathrm{~min}$ at $0^{\circ}$, excess borane was destroyed by cautious addition of $\mathrm{H}_{2} \mathrm{O}$. After addition of cold $3 \mathrm{~N} \mathrm{HCl}, \mathrm{CHCl}_{3}$ extraction was performed. The extract was dried $\left(\mathrm{MgSO}_{4}\right)$ and concd in vacuo, giving product 22 in $100 \%$ yield. Mp $65^{\circ} .{ }^{1} \mathrm{H}$ NMR: $\delta 2.06(1 \mathrm{H}, \mathrm{br} \mathrm{s}, \mathrm{OH}), 2.44(3 \mathrm{H}$, $s, \operatorname{ArMe}), 4.63\left(2 \mathrm{H}, s, \mathrm{ArCH}_{2} \mathrm{O}\right), 6.7-7.4(6 \mathrm{H}, m, \mathrm{ArH}), 7.72(2 \mathrm{H}, d$, $J=8.7 \mathrm{~Hz}$, tosyl-H). GC/MS $m / z$ (rel. int.): 278 (26), 155 (59), 123 (12), 92 (10), 91 (100).

3-Tosyloxybenzylchloride (23). Compound 22 was treated with $\mathrm{SOCl}_{2}$ as reported for the synthesis of 18 . The yield of 23 was $95 \%$. Mp 59. ${ }^{1} \mathrm{H}$ NMR: $\delta 2.43(3 \mathrm{H}, s, \operatorname{ArMe}), 4.48(2 \mathrm{H}, s$, $\left.\mathrm{ArCH}_{2} \mathrm{Cl}\right), 6.8-7.4(6 \mathrm{H}, m, \mathrm{ArH}), 7.72(2 \mathrm{H}, d, J=8.7 \mathrm{~Hz}$, tosylH). GC/MS $m / z$ (rel. int.): 298 (11), 296 (26), 155 (98), 91 (100), 77 (10).

3-Tosyloxybenzylcyanide (24). Compound 23 was treated with $\mathrm{KCN}$ in DMSO, as in the synthesis of 19. The yield of 24 was $86 \%$. Mp 69 ${ }^{\circ}{ }^{1} \mathrm{H}$ NMR: $\delta 2.44(3 \mathrm{H}, s, \operatorname{ArMe}), 3.69(2 \mathrm{H}, s$, $\left.\mathrm{ArCH}_{2} \mathrm{CN}\right), 6.7-7.5(6 \mathrm{H}, m, \mathrm{ArH}), 7.72(2 \mathrm{H}, d, J=8.7 \mathrm{~Hz}$, tosylH). GC/MS $m / z$ (rel. int.): 287 (25), 155 (78), 92 (8), 91 (100).

3-Tosyloxyphenethylamine (25). To a mixture of $24(5.74 \mathrm{~g})$ and $\mathrm{NaBH}_{4}(0.43 \mathrm{~g})$ in dry THF $(60 \mathrm{ml}) \mathrm{BF}_{3} \cdot \mathrm{OEt}_{2}(1.9 \mathrm{ml})$ was added dropwise while stirring at $0^{\circ}$. The soln was then stirred at room temp for 6 days and decomposed with $\mathrm{EtOH}, \mathrm{H}_{2} \mathrm{O}$ and dil aq. $\mathrm{HCl}$, respectively, and evaporated. The residue was neutralized with aq. $\mathrm{NH}_{3}$ and extracted with $\mathrm{CHCl}_{3}$. The $\mathrm{CHCl}_{3}$ extract was washed with $\mathrm{H}_{2} \mathrm{O}$, dried $\left(\mathrm{Na}_{2} \mathrm{SO}_{4}\right)$, and evaporated to give the amine $25(5.82 \mathrm{~g}$, yield $100 \%)$. Oil. ${ }^{1} \mathrm{H}$ NMR: $\delta 1.27(2 \mathrm{H}, \mathrm{br} \mathrm{s}$, $\left.\mathrm{NH}_{2}\right), 2.43(3 \mathrm{H}, \mathrm{s}, \mathrm{ArMe}), 2.5-3.0\left(4 \mathrm{H}, \mathrm{m}, 2 \times \mathrm{CH}_{2}\right), 6.7-7.4(6 \mathrm{H}$, $m, \operatorname{ArH}), 7.72(2 \mathrm{H}, d, J=9 \mathrm{~Hz}$, tosyl-H). GC/MS $m / z$ (rel. int.): 292 (3), 291 (11), 262 (2), 155 (30), 136 (35), 107 (26), 92 (11), 91 (100), $90(10)$.

N-(3-Tosyloxyphenethyl)-2-(2-bromo-3-isopropoxy-4-methoxyphenyl)acetamide (26). A mixture of $20(6.06 \mathrm{~g})$ and $25(5.82 \mathrm{~g})$ in decalin $(135 \mathrm{ml})$ was heated under reflux for $2.5 \mathrm{hr}$. After cooling, the mixture was evaporated to dryness and the residue dissolved in $\mathrm{CHCl}_{3}$. The $\mathrm{CHCl}_{3}$ soln was shaken thoroughly with $5 \%$ aq. $\mathrm{HCl}, 2 \%$ aq NaOH and $\mathrm{H}_{2} \mathrm{O}$. The soln was dried $\left(\mathrm{Na}_{2} \mathrm{SO}_{4}\right)$ and 
evaporated to give the amide $26(9.68 \mathrm{~g}$, yield $84 \%)$. Oil. Acidification of the basic washings and $\mathrm{CHCl}_{3}$ extraction recovered some 20 . When corrected for recovered acid 20 , the yield of 26 was $100 \% .{ }^{1} \mathrm{H}$ NMR: $\delta 1.31\left(6 \mathrm{H}, d, J=6 \mathrm{~Hz}, \mathrm{CMe}_{2}\right)$, $2.43(3 \mathrm{H}, s, \mathrm{ArMe}), 2.64\left(2 \mathrm{H}, t, J=7 \mathrm{~Hz}, \mathrm{ArCH}_{2} \mathrm{CH}_{2} \mathrm{~N}\right), 3.33$ ( $2 \mathrm{H}$, double $t, J=6 \mathrm{~Hz}, J=7 \mathrm{~Hz}, \mathrm{ArCH}_{2} \mathrm{CH}_{2} \mathrm{NH}$ ), $3.63(2 \mathrm{H}, s$, $\left.\mathrm{ArCH}_{2} \mathrm{CO}\right), 3.84(3 \mathrm{H}, s, \mathrm{OMe}), 4.57\left(1 \mathrm{H}, m, J=6 \mathrm{~Hz}, \mathrm{CHMe}_{2}\right)$, $5.36(1 \mathrm{H}, b r t, J=6 \mathrm{~Hz}, \mathrm{NH}), 6.6-7.8(10 \mathrm{H}, m, \mathrm{ArH})$.

$\mathrm{N}$-(3-Hydroxyphenethyl)-2-(2-bromo-3-isopropoxy-4-methoxyphenyl) acetamide (27). To a stirred soln of $26(9.1 \mathrm{~g})$ in $\mathrm{MeOH}$ $(50 \mathrm{ml})$ and DMF $(50 \mathrm{ml}) \mathrm{KOH}(3.64 \mathrm{~g})$ was added and the reaction mixture stirred at $60^{\circ}$ for $3 \mathrm{hr}$. After cooling, the mixture was poured into $\mathrm{H}_{2} \mathrm{O}$, treated with $\mathrm{HCl}$ and extracted with $\mathrm{CHCl}_{3}$. The $\mathrm{CHCl}_{3}$ extract was washed with $\mathrm{H}_{2} \mathrm{O}$, dried $\left(\mathrm{Na}_{2} \mathrm{SO}_{4}\right)$, and evaporated to give the phenolic compound 27 in $92 \%$ yield. Colourless oil. ${ }^{1} \mathrm{H}$ NMR: $\delta 1.32(6 \mathrm{H}, d, J=6 \mathrm{~Hz}$, $\left.\mathrm{CMe}_{2}\right), 2.60\left(2 \mathrm{H}, t, J=7 \mathrm{~Hz}, \mathrm{ArCl}_{2} \mathrm{CH}_{2} \mathrm{~N}\right), 3.43(2 \mathrm{H}$, double $t$, $\left.J=6 \mathrm{~Hz}, J=7 \mathrm{~Hz}, \mathrm{ArCH}_{2} \mathrm{CH}_{2} \mathrm{NH}\right), 3.65\left(2 \mathrm{H}, s, \mathrm{ArCH}_{2} \mathrm{CO}\right)$, $3.83(3 \mathrm{H}, s, \mathrm{OMe}), 4.63(1 \mathrm{H}, m, J=6 \mathrm{~Hz}, \mathrm{CHMe}), 5.46(1 \mathrm{H}, b r t$, $J=6 \mathrm{~Hz}, \mathrm{NH}), 6.5-7.3(6 \mathrm{H}, m, \mathrm{ArH})$. GC/MS $m / z$ (rel. int.): 423 (9), 421 (10), 342 (31), 300 (58), 217 (48), 215 (48), $180(100), 121$ (67), 120 (40), 77 (30).

Photolysis of 27 . Compound $27(500 \mathrm{mg})$ in $\mathrm{MeOH}(250 \mathrm{ml})$ containing $\mathrm{NaOH}(400 \mathrm{mg})$, was irradiated for 50 min using a 125 W high-pressure Hg lamp (Philips HPLN $57236 \mathrm{E} / 74$, from which the outer bulb was removed) in a quartz immersion apparatus, while a stream of $\mathrm{N}_{2}$ was passed through the soln. The solvent was removed in vacuo and the residue dissolved in $\mathrm{H}_{2} \mathrm{O}$, whereupon $\mathrm{Et}_{2} \mathrm{O}$ extraction was performed. The aq. phase was neutralized (conc $\mathrm{HCl}$ ) and extracted with $\mathrm{CHCl}_{3}$. The extract was washed with $\mathrm{H}_{2} \mathrm{O}$, dried $\left(\mathrm{MgSO}_{4}\right)$ and evaporated. From a $\mathrm{CHCl}_{3}$ soln of the products from $4.45 \mathrm{~g} 27$ upon cooling some 29 crystallized. Recrystallization from $\mathrm{CHCl}_{3}$ gave $1.33 \mathrm{~g}$ 29. $\mathrm{Mp}$ $256^{\circ}$. The mother liquors were separated by silica gel chromatography, using $\mathrm{CHCl}_{3}-\mathrm{MeOH}$ mixtures $(0-15 \% \mathrm{MeOH})$. This yielded a mixed fraction of 28 and $30(421 \mathrm{mg})$ and finally crude $29(1.10 \mathrm{~g})$. The latter fraction was crystallized and further purified by silica gel chromatography using EtOAc- $n$ hexane-MeOH (75:25: 1). The yield of 29 was $2.06 \mathrm{~g}(58 \%)$. The fraction containing 28 and 30 was chromatographed in a similar manner giving first $28(230 \mathrm{mg}$, yield $6 \%)$, and then $30(87 \mathrm{mg}$, yield $2.4 \%$ ) (see Scheme 2).

$\mathrm{N}-(3-H y d r o x y p h e n e t h y l)-2-(3-i s o p r o p o x y-4-m e t h o x y p h e n y l)$ acetamide (28). ${ }^{1} \mathrm{H}$ NMR: $\delta 1.31\left(6 \mathrm{H}, d, J=6 \mathrm{~Hz}, \mathrm{CMe}_{2}\right), 2.63$ $\left(2 \mathrm{H}, t, J=7 \mathrm{~Hz}, \operatorname{ArCH}_{2} \mathrm{CH}_{2} \mathrm{~N}\right), 3.41(2 \mathrm{H}$, ' $q$ ', $J=6 \mathrm{~Hz}, J$ $\left.=7 \mathrm{~Hz}, \mathrm{ArCH}_{2} \mathrm{CH}_{2} \mathrm{NH}\right), 3.46\left(2 \mathrm{H}, s, \mathrm{ArCH}_{2} \mathrm{CO}\right), 3.82(3 \mathrm{H}, s$, $\mathrm{OMe}), 4.46\left(1 \mathrm{H}, m, J=6 \mathrm{~Hz}, \mathrm{CHMe}_{2}\right), 5.80(1 \mathrm{H}, t, J=6 \mathrm{~Hz}$, NH), 6.4-7.2 (7H, $m$, ArH), $7.7(1 \mathrm{H}$, br $s, \mathrm{OH})$. GC/MS $m / z$ (rel. int ): 344 (10), 343 (42), 301 (5), 182 (15), 181 (87), 166 (11), 138 (37), 137 (100), 123 (12), 122 (11), 121 (16), 120 (15).

5,8,9-Trihydro-1-isopropoxy-2-methoxy-6-oxo-7H-dibenz $[d, f]$ azonin-11-ol (29). ${ }^{1} \mathrm{H}$ NMR: $\delta 0.72$ and $1.04(6 \mathrm{H}, 2 \times b r d, J$ $\left.=6 \mathrm{~Hz}, \mathrm{CMe}_{2}\right), 2.1-4.7(7 \mathrm{H}, m), 3.87(3 \mathrm{H}, s, \mathrm{OMe}), 3.98(1 \mathrm{H}, m, J$ $\left.=6 \mathrm{~Hz}, \mathrm{CHMe}_{2}\right), 5.9(1 \mathrm{H}, b r s, \mathrm{OH}), 6.5-7.2(5 \mathrm{H}, m$, all resonances being broadened, ArH). GC/MS $m / z$ (rel. int.): 342 (14), 341 (56), 300 (18), 299 (100), 270 (18), 242 (40), 241 (13), 211 (15), 209 (13), 181 (14).

5,8,9-Trihydro-1-isopropoxy-2-methoxy-6-oxa-7H-dibenz $[d, f]$ azonin-13-ol- (30). Mp 158-170 ${ }^{\circ}{ }^{1} \mathrm{H}$ NMR: $\delta 0.8$ and $1.05(6 \mathrm{H}$, two very broad bands, $\left.\mathrm{CMe}_{2}\right), 3.88(3 \mathrm{H}, s, \mathrm{OMe}), 4.03(1 \mathrm{H}, m, J$ $\left.=6 \mathrm{~Hz}, \mathrm{CHMe}_{2}\right), 6.2-7.3(5 \mathrm{H}, m, \mathrm{ArH})$. In $\mathrm{CD}_{3} \mathrm{OD}$ at $200 \mathrm{MHz}$ the $\mathrm{CMe}_{2}$ resonances were observed as four doublets, at $\delta 0.73$, $0.86,0.98$ and 1.08 , together integrating for $6 \mathrm{H}$. This integral was divided in the $c a$ proportion $5: 4: 4: 5$, respectively. The peak heights of the outer two resonances were 1.7 times those of the inner resonances. $J$ was $6 \mathrm{~Hz}$. The OMe resonance was a sharp $s$<smiles>[R]c1ccc(CCNC(=O)Cc2c([R])cc([R])c([R])c2Br)cc1O</smiles><smiles>CO[N+]([O-])([O-])O</smiles><smiles>[R]c1cc([R2])c(CC(=O)NCCc2ccc([R7])c(O)c2-c2c([R])cc([R])c([R])c2[R])c([R])c1</smiles>
$+$<smiles>[R]c1cc([R])c(CC(=O)NCCc2cc(O)c([R4])cc2-c2cc([R])c([R])cc2[R])c([R])c1</smiles><smiles>[R]c1ccc(CCNC(=O)Cc2c([R])cc([R])c([R])c2[R])cc1O</smiles>

A

B

\begin{tabular}{lcccllllc}
\hline & \multicolumn{2}{c}{ Products } & & & & \\
Substrate & A & B & C & $\mathbf{R}^{1}$ & $\mathbf{R}^{2}$ & $\mathbf{R}^{3}$ & $\mathbf{R}^{4}$ & Final product \\
\hline 27 & 28 & 30 & 29 & OCHMe & OMe & H & H & 2 \\
39 & 40 & 41 & 42 & H & H & OMe & OMe & 9 \\
\hline
\end{tabular}

Scheme 2. Substrates for and products of the photolytic aryl-aryl coupling reaction. 
at $\delta$ 3.87. At $50^{\circ}$ the $\mathrm{CMe}_{2}$ resonances were broadening, and at $75^{\circ}$ almost complete collapse to a broad unresolved band was observed. GC/MS $m / z$ (rel. int.): 342 (18), 341 (59), 300 (21), 299 (100), $270(30), 242$ (52), 181 (18).

5,8,9-Trihydro-2,11-dimethoxy-1-isopropoxy-6-oxo-7H-dibenz$[d, f]$ azonin (31). To a suspension of $29(600 \mathrm{mg})$ and dry $\mathrm{K}_{2} \mathrm{CO}_{3}$ $(300 \mathrm{mg})$ in dry EtOH was added dropwise excess $\mathrm{MeI}(0.3 \mathrm{ml})$ at room temp during $10 \mathrm{~min}$. The stirred mixture was heated at $50^{\circ}$ for $6 \mathrm{hr}$, evaporated and dissolved in warm $\mathrm{CHCl}_{3}$. The $\mathrm{CHCl}_{3}$ soln was washed with $\mathrm{H}_{2} \mathrm{O}$, dried $\left(\mathrm{Na}_{2} \mathrm{SO}_{4}\right)$ and evaporated. The crude yield was $97 \%$. The products, obtained by methylation of $1.63 \mathrm{~g} 29$ were purified by silica gel chromatography, using $\mathrm{CHCl}_{3}-\mathrm{EtOAc}(3: 1)$, which yielded $1.21 \mathrm{~g} 31$ (yield $71 \%$ ). ${ }^{1} \mathrm{H}$ NMR: $\delta 0.80$ and $0.97\left(6 \mathrm{H}\right.$, two very broad bands, $\left.\mathrm{CMe}_{2}\right), 3.85$ (3H, $s, \mathrm{OMe}), 3.87(3 \mathrm{H}, s, \mathrm{OMe}), 6.33(1 \mathrm{H}, b r), 6.6-7.5(5 \mathrm{H}, \mathrm{m}$, ArH). GC/MS $m / z$ (rel. int.): 356 (10), 355 (46), 314 (19), 313 (100), 284 (18), 256 (27), 225 (10).

5,8,9-Trihydro-2,11-dimethoxy-6-oxo-7H-dibenz [d,f]azonin-1ol (32). A soln of $31(840 \mathrm{mg})$ in HOAc $(53 \mathrm{ml})$ containing conc $\mathrm{HBr}(4.2 \mathrm{ml})$ was heated with stirring at $80^{\circ}$ for $1.5 \mathrm{hr}$. After cooling the mixture was poured into ice- $\mathrm{H}_{2} \mathrm{O}$ and then extracted with $\mathrm{CHCl}_{3}$. The $\mathrm{CHCl}_{3}$ extract was washed with $\mathrm{H}_{2} \mathrm{O}$, dried $\left(\mathrm{Na}_{2} \mathrm{SO}_{4}\right)$ and evaporated to afford $32(691 \mathrm{mg}$, yield $93 \%)$. ${ }^{1} \mathrm{H}$ NMR: $\delta 3.79$ (3H, $\left.s, \mathrm{OMe}\right), 3.88(3 \mathrm{H}, s$, OMe), $5.9(1 \mathrm{H}, b r s$, $\mathrm{OH}), 6.77 .3$ (5H, $m, \mathrm{ArH})$.

5,6,8,9-Tetrahydro-2,11-dimethoxy-7H-dibenz $[d, f] a z o n i n-1-o l$ (33). To a cold suspension of $32(326 \mathrm{mg})$ and $\mathrm{NaBH}_{4}(227 \mathrm{mg})$ in dry THF $(30 \mathrm{ml}) \mathrm{BF}_{3} \cdot \mathrm{OEt}_{2}(0.8 \mathrm{ml})$ was added dropwise in $15 \mathrm{~min}$. After stirring at room temp for $6 \mathrm{hr}$, excess borane was destroyed by slow addition of EtOH $(2 \mathrm{ml})$, followed by addition of $\mathrm{H}_{2} \mathrm{O}(3 \mathrm{ml})$ and conc $\mathrm{HCl}(1 \mathrm{ml})$. The reaction mixture was concd in vacuo and the residue treated with $\mathrm{H}_{2} \mathrm{O}$ and conc aq. $\mathrm{NH}_{3}$ until pH 8-9 was reached, and then extracted with $\mathrm{CHCl}_{3}$. The $\mathrm{CHCl}_{3}$ extract was washed with $\mathrm{H}_{2} \mathrm{O}$, dried $\left(\mathrm{MgSO}_{4}\right)$ and evaporated. Yield $96 \%$. Mp 212 ${ }^{\circ}{ }^{1} \mathrm{H}$ NMR: $\delta 2.0-3.2(10 \mathrm{H}, \mathrm{m})$, $3.84(3 \mathrm{H}, s, \mathrm{OMe}), 3.91$ (3H, $s, \mathrm{OMe}), 6.6-6.93(4 \mathrm{H}, m, \mathrm{ArH})$, 7.0-7.2 (1H, $m, \mathrm{ArH})$. GC/MS $m / z$ (rel. int.): 300 (21), 299 (100), 257 (26), 256 (13), 255 (16), 253 (26), 242 (12), 240 (19), 226 (11), 225 (36), 223 (12).

Bractazonine (2). A $37 \%$ aq. HCHO soln $(0.15 \mathrm{ml})$ was added to a soln of $33(109 \mathrm{mg})$ in $\mathrm{MeOH}(20 \mathrm{ml})$ and the mixture stirred at room temp. for $0.5 \mathrm{hr}$. The mixture was cooled to $5-10^{\circ}$ and $\mathrm{NaBH}_{4}(144 \mathrm{mg})$ was added in small portions during $10 \mathrm{~min}$. After continued stirring for $30 \mathrm{~min}$ at room temp, the mixture was evaporated to dryness and dissolved in $\mathrm{CHCl}_{3}$. The $\mathrm{CHCl}_{3}$ extract was washed with $\mathrm{H}_{2} \mathrm{O}$, dried $\left(\mathrm{Na}_{2} \mathrm{SO}_{4}\right)$ and evaporated, to give 2 (107 mg, yield $94 \%$ ). Mp $101^{\circ} .{ }^{1} \mathrm{H}$ NMR: $\delta 2.28(3 \mathrm{H}, s$, $\mathrm{NMe}$ ), 2.3-2.7 (8H, $m, 4 \times \mathrm{CH}_{2}$ ), 3.84 (3H, $\left.s, \mathrm{OMe}\right), 3.90$ (3H, $s$, $\mathrm{OMe}), 5.3(1 \mathrm{H}, b r s, \mathrm{OH}), 6.70$ and 6.84 (2H, AB-pattern, $J$ $=8.3 \mathrm{~Hz}, \mathrm{H}-3$ and $\mathrm{H}-4), 6.82(1 \mathrm{H}, d, J=2.7 \mathrm{~Hz}, \mathrm{H}-10), 6.82(1 \mathrm{H}$, $d d, J=2.7 \mathrm{~Hz}, J=9.2 \mathrm{~Hz}, \mathrm{H}-12), 7.09(1 \mathrm{H}, d, J=9.2 \mathrm{~Hz}, \mathrm{H}-13)$. The observed $\Delta \delta$ (OMe) was 0.068 . GC/MS $m / z$ (rel. int.): 314 (22), 313 (100), 312 (14), 298 (15), 296 (24), 270 (27), 257 (15), 256 (28), 255 (32), 239 (15), 225 (14), 223 (30)

Synthesis of 9 . The starting materials for the preparation of the substrate for the photolytic coupling reaction, leading ultimately to 9, were 2-bromo-6-methoxybenzoic acid and 3-benzyloxy-4methoxyphenethylamine.

2-Bromo-6-methoxybenzylalcohol (34). 2-Bromo-6-methoxybenzoic acid [34] in dry THF was reduced in an $\mathrm{N}_{2}$ atmosphere at room temp using excess borane in THF. The reaction proceeded slowly as monitored by GC. After 3 days, excess hydride was destroyed by cautious addition of a mixture of THF and $\mathrm{H}_{2} \mathrm{O}(1: 1)$. The aq. phase was satd with $\mathrm{K}_{2} \mathrm{CO}_{3}$, whereupon the THF layer was separated and the $\mathrm{H}_{2} \mathrm{O}$ layer extracted with $\mathrm{Et}_{2} \mathrm{O}$. The combined extracts were dried $\left(\mathrm{MgSO}_{4}\right)$ and concd in vacuo. The yield of 34 was $66 \%$, while $30 \%$ starting material was recovered upon acidification of the aq. phase. $\mathrm{Mp} 75^{\circ}\left(\mathrm{Et}_{2} \mathrm{O}\right.$ and MeOH). ${ }^{1} \mathrm{H}$ NMR: $\delta 2.53(1 \mathrm{H}, b r s, \mathrm{OH}), 3.86(3 \mathrm{H}, s, \mathrm{OMe}), 4.88$ (2H, s, $\left.\mathrm{ArCH}_{2} \mathrm{OH}\right), 6.7-7.3(3 \mathrm{H}, m, \mathrm{ArH})$. Upon computer simulation of the $\mathrm{ABC}$ pattern obtained for the aromatic protons excellent agreement was obtained for $\delta 6.84(\mathrm{H}-5), 7.11(\mathrm{H}-4)$ and $7.18(\mathrm{H}-3)$, with $J_{3,4}=7.9 \mathrm{~Hz}, J_{3,5}=2.3 \mathrm{~Hz}$ and $J_{4,5}=7.1 \mathrm{~Hz}$. GC/MS $m / z$ (rel. int.): 218 (77), 217 (14), 216 (79), 203 (13), 201 (28), 199 (16), 187 (16), 185 (30), 183 (15), 171 (11), 169 (10), 137 (66), 136 (14), 109 (100), 108 (13), 94 (33), 91 (15), 90 (11).

2-Bromo-6-methoxybenzylchloride (35). Compound 34 was treated with $\mathrm{SOCl}_{2}$, as in the synthesis of 18, which gave compound 35 in $96 \%$ yield. Mp $47^{\circ}$. ${ }^{1} \mathrm{HNMR}$ : $\delta 3.88(3 \mathrm{H}, \mathrm{s}$, $\mathrm{OMe}$ ), 4.83 (2H, $s, \mathrm{ArCH}_{2} \mathrm{Cl}$ ), 6.83, 7.15 and 7.20 (ABC-pattern for $\mathrm{H}-5, \mathrm{H}-4$ and $\mathrm{H}-3$, respectively, very similar to that observed in 34). GC/MS $m / z$ (rel. int.): 238 (10), 236 (40), 234 (31), 202 (9), 201 (99), 200 (9), 199 (100), 171 (40), 169 (39), 90 (27).

2-Bromo-6-methoxybenzylcyanide (36). Treatment of 35 with $\mathrm{KCN}$ in DMSO afforded 36 in $96 \%$ yield. Mp $49^{\circ}$. ${ }^{1} \mathrm{H}$ NMR: $\delta 3.85\left(2 \mathrm{H}, s, \mathrm{ArCH}_{2} \mathrm{CN}\right), 3.87(3 \mathrm{H}, s, \mathrm{OMe}), 6.7-7.3$ (3H, $m, \mathrm{ArH}$, very similar to 34 and 35). GC/MS $m / z$ (rel. int.): 227 (99), 225 (100), 212 (22), 210 (23), 187 (37), 185 (39), 146 (28).

2-Bromo-6-methoxyphenylacetic acid (37). Hydrolysis of 36 in a similar way to the preparation of 20 , gave 37 in $88 \%$ yield. Mp $180^{\circ} .{ }^{1} \mathrm{H}$ NMR: $\delta 3.82(3 \mathrm{H}, s, \mathrm{OMe}), 3.93\left(2 \mathrm{H}, s, \mathrm{ArCH}_{2} \mathrm{COOH}\right)$, 6.7-7.3 (3H, $m, \mathrm{ArH}$, pattern similar to that mentioned above), 8.7 (1H, br s, COOH). GC/MS $m / z$ (rel. int.): 246 (53), 244 (54), 202 (34), 201 (47), 200 (36), 199 (45), 171 (53), 169 (53), 165 (100).

N-(3-Benzyloxy-4-methoxyphenethyl)-2-(2-bromo-6-methoxyphenyl)acetamide (38). Heating 3-benzyloxy-4-methoxyphenethylamine [35] and 2-bromo-6-methoxyphenylacetic acid (37) in decalin, afforded 38 in $70 \%$ yield. Acidification of the basic washings, followed by $\mathrm{CHCl}_{3}$ extraction, recovered unreacted 37 , making the corrected yield of $38100 \%$ Mp $136^{\circ}$ (decomp. from MeOH). ${ }^{1} \mathrm{H}$ NMR: $\delta 2.62\left(2 \mathrm{H}, t, J=7 \mathrm{~Hz}, \mathrm{ArCH}_{2} \mathrm{CH}_{2} \mathrm{~N}\right), 3.39$ $\left(2 \mathrm{H}\right.$, double $\left.t, J=6 \mathrm{~Hz}, J=7 \mathrm{~Hz}, \mathrm{ArCH}_{2} \mathrm{CH}_{2} \mathrm{NH}\right), 3.73(3 \mathrm{H}, s$, OMe), 3.75 (2H, $s, \mathrm{ArCH}_{2} \mathrm{CO}$ ), 3.85 ( $\left.3 \mathrm{H}, s, \mathrm{OMe}\right), 5.07$ ( $2 \mathrm{H}, s$, $\left.\mathrm{ArCH}_{2} \mathrm{O}\right), 5.42(1 \mathrm{H}$, br $t, J=6 \mathrm{~Hz}, \mathrm{NH}), 6.5-7.5(11 \mathrm{H}, m, \mathrm{ArH})$, GC/MS $m / z$ (rel. int.): 485 (1.6), 483 (1.6), 241 (7), 240 (40), 201 (6), 199 (6), 166 (6), 150 (11), 92 (9), 91 (100), 90 (5).

$\mathrm{N}$-(3-Hydroxy-4-methoxyphenethyl)-2-(2-bromo-6-methoxyphenyl)acetamide (39). A stirred soln of $38(4.0 \mathrm{~g})$ in conc $\mathrm{HCl}$ $(40 \mathrm{ml})$ and $\mathrm{EtOH}(40 \mathrm{ml})$ was heated at $60^{\circ}$ for $6 \mathrm{hr}$. The volatile materials were removed, $\mathrm{H}_{2} \mathrm{O}$ was added, and the mixture extracted with $\mathrm{CHCl}_{3}$. The extract was washed with $\mathrm{H}_{2} \mathrm{O}$, dried $\left(\mathrm{Na}_{2} \mathrm{SO}_{4}\right)$ and evaporated, producing the debenzylated amide 39 (3.22 g, yield $99 \%$ ). Mp $118^{\circ}$ (decomp. from $\mathrm{MeOH}-\mathrm{Et}_{2} \mathrm{O}$ ). ${ }^{1} \mathrm{H}$ NMR: $\delta 2.62\left(2 \mathrm{H}, t, J=7 \mathrm{~Hz}, \mathrm{ArCH}_{2} \mathrm{CH}_{2} \mathrm{~N}\right), 3.42(2 \mathrm{H}$, double $\left.t, J=6 \mathrm{~Hz}, J=7 \mathrm{~Hz}, \mathrm{ArCH}_{2} \mathrm{CH}_{2} \mathrm{NH}\right), 3.78(5 \mathrm{H}, s, \mathrm{OMe}$ $\left.+\mathrm{ArC}_{2}{ }_{2} \mathrm{CO}\right), 3.85(3 \mathrm{H}, s, \mathrm{OMe}), 5.46(1 \mathrm{H}, b r t, \mathrm{NH}), 5.65(1 \mathrm{H}, b r$ $s, \mathrm{OH}), 6.45-7.4$ (6H, $m, \mathrm{ArH}), \mathrm{GC} / \mathrm{MS} m / z$ (rel int.): 395 (1.6), 393 (1.6), 246 (1.4), 244 (1.4), 201 (12), 199 (12), 151 (13), 150 (100), 137 (11), 135 (8), 91 (8), 90 (5).

Photolysis of 39. Compound $39(6.7 \mathrm{~g})$ was irradiated in $500 \mathrm{mg}$ aliquots for $25 \mathrm{~min}$, similarly to the photolysis of 27 . The products were chromatographed on silica gel, first using $\mathrm{CHCl}_{3}$, followed by $\mathrm{CHCl}_{3}-\mathrm{Me}_{2} \mathrm{CO}(99: 1)$. The elution order was 40 , then 41 and finally 42 . The products were not fully separated. Fractions containing mainly 41 , respectively 42 , were crystallized from $\mathrm{Et}_{2} \mathrm{O}-\mathrm{MeOH}$, yielding pure $41(0.77 \mathrm{~g})$ and pure $42(1.2 \mathrm{~g})$. The mother liquor and the fractions containing mainly 40 were combined ( $1.67 \mathrm{~g}$ ), and chromatographed on $\mathrm{Al}_{2} \mathrm{O}_{3}$ (activity III), eluted with $\mathrm{CHCl}_{3}$ satd with $\mathrm{H}_{2} \mathrm{O}$, followed by $\mathrm{CHCl}$ - $\mathrm{MeOH}$ mixtures, up to $19: 1$. This yielded $\mathbf{4 1}(0.3 \mathrm{~g})$, then a mixture of $\mathbf{4 0}$ and $39\left(0.78 \mathrm{~g}\right.$, ca $25 \% 39$ by ${ }^{1} \mathrm{H}$ NMR), and finally $42(0.32 \mathrm{~g})$. The yield of 41 was $32 \%$, that of 42 was $28 \%$. The yield of 40 was 
ca $10 \%$, while ca $3 \%$ starting material was present (see Scheme 2 ).

$\mathrm{N}-(3-H y d r o x y-4-m e t h o x y p h e n e t h y l)-2-(6-$ methoxyphenyl)acetamide (40). ${ }^{1} \mathrm{H}$ NMR: $\delta 2.59\left(2 \mathrm{H}, t, J=7 \mathrm{~Hz}, \mathrm{ArC}_{2}{ }_{2} \mathrm{CH}_{2} \mathrm{~N}\right), 3.40$ (2H, double $\left.t, J=6 \mathrm{~Hz}, J=7 \mathrm{~Hz}, \mathrm{ArCH}_{2} \mathrm{CH}_{2} \mathrm{NH}\right), 3.51(2 \mathrm{H}, s$, $\mathrm{ArCH}_{2} \mathrm{CO}$ ). GC/MS m/z (rel. int.): 315 (5), 222 (6), 166 (5), 151 (12), 150 (100), 137 (10), 135 (8), 122 (6), 121 (28).

5,6,9-Trihydro-2,10-dimethoxy-8-oxo-7H-dibenz [d,f]azonin-1ol (41). $\mathrm{Mp} 238^{\circ}$ (from $\mathrm{Et}_{2} \mathrm{O}-\mathrm{MeOH}$ ). ${ }^{1} \mathrm{H}$ NMR: $\delta 2.50(2 \mathrm{H}, \mathrm{m})$, 3.08 and $4.22\left(2 \mathrm{H}, \mathrm{AB}\right.$-pattern, $\left.J=17 \mathrm{~Hz}, \mathrm{ArCH}_{2} \mathrm{CO}\right), 3.1,3.6$ and $4.4(3 \mathrm{H}, b r), 3.86(6 \mathrm{H}, s, 2 \times \mathrm{OMe}), 5.53(1 \mathrm{H}, s, \mathrm{OH}), 6.65-7.05$ (4H, $m, \mathrm{ArH}), 7.2-7.45(1 \mathrm{H}, m, \mathrm{H}-12)$. In the pattern obtained for the aromatic protons, the AB-pattern for $\mathrm{H}-3$ and $\mathrm{H}-4(\delta 6.72$ and $6.88, J=8.4 \mathrm{~Hz}$ ) was recognisable, though somewhat obscured by the resonances of $\mathrm{H}-11$ and $\mathrm{H}-13$. GC/MS $m / z$ (rel. int.): 314 (19), 313 (100), 284 (41), 257 (21), 256 (72), 255 (11), 241 (18), 225 (21), 223 (17).

5,6,9-Trihydro-2,10-dimethoxy-8-oxo-7H-dibenz $[d, f]$ azonin-3ol (42). $\mathrm{Mp} 216^{\circ}$ (from $\left.\mathrm{Et}_{2} \mathrm{O}-\mathrm{MeOH}\right){ }^{\mathrm{t}} \mathrm{H}$ NMR: $\delta 2.50(2 \mathrm{H}, \mathrm{m}$ ), 3.17 and $4.20\left(2 \mathrm{H}, \mathrm{AB}\right.$-pattern, $\left.J=18 \mathrm{~Hz}, \mathrm{ArCH}_{2} \mathrm{CO}\right), 3.15,3.7$ and $4.3(3 \mathrm{H}, b r), 3.79(3 \mathrm{H}, s, \mathrm{OMe}), 3.88(3 \mathrm{H}, \mathrm{s}, \mathrm{OMe}), 5.83(1 \mathrm{H}, b r$ $s, \mathrm{OH}), 6.46(1 \mathrm{H}, s, \mathrm{H}-4), 6.74(1 \mathrm{H}, s, \mathrm{H}-1), 6.7-7.0(2 \mathrm{H}, m, \mathrm{H}-11$ and $\mathrm{H}-13), 7.15-7.4(1 \mathrm{H}, m, \mathrm{H}-12)$. In DMSO- $d_{6}$ the resonances of the aromatic protons were better resolved: $\delta 6.43$ and $6.60(2 \mathrm{H}, 2$ $\times s, \mathrm{H}-4$ and $\mathrm{H}-1$, respectively), $6.69(1 \mathrm{H}, d d, J=1.3 \mathrm{~Hz}, J$ $=7.2 \mathrm{~Hz}, \mathrm{H}-11), 7.04(1 \mathrm{H}, d d, J=1.3 \mathrm{~Hz}, J=8.4 \mathrm{~Hz}, \mathrm{H}-13), 7.27$ $(1 \mathrm{H}, d d, J=7.2 \mathrm{~Hz}, J=8.4 \mathrm{~Hz}, \mathrm{H}-12$ ). GC/MS $m / z$ (rel. int.): 314 (19), 313 (100), 284 (42), 257 (21), 256 (59), 255 (16), 241 (18), 225 (27).

5,6,8,9-Tetrahydro-2,10-dimethoxy-7H-dibenz $[d, f]$ azonin-1-ol (43). Compound 41 was treated with in situ prepared diborane, similar to the synthesis of 33 , giving 43 in $100 \%$ yield. Mp $100^{\circ}$. ${ }^{1}$ H NMR: $\delta 1.8-4.0(10 \mathrm{H}, m), 3.84$ (3H, $\left.s, \mathrm{OMe}\right), 3.91$ (3H, $s$, OMe), 6.6-7.0 (4H, $m, \operatorname{ArH}), 7.27(1 \mathrm{H}, d d, J=7.5 \mathrm{~Hz}, J=8.4 \mathrm{~Hz}$, H-12). GC/MS m/z (rel. int.): 300 (21), 299 (100), 282 (10), 268 (25), 257 (22), 256 (23), 255 (29), 253 (22), 240 (16), 239 (11), 226 (11), 225 (40), 223 (14).

5,6,8,9-Tetrahydro-2,10-dimethoxy-7-methyl-dibenz $[d, f] a z o n i n-$ 1-ol (9). Compound 43 was $N$-methylated in the manner, described for the synthesis of 2 from 33, giving a quantitative yield of 9. Mp $166^{\circ} .{ }^{1} \mathrm{H}$ NMR: $\delta 2.27(3 \mathrm{H}, \mathrm{s}, \mathrm{NMe}), 2.0-3.1(8 \mathrm{H}, \mathrm{m}$, $\left.4 \times \mathrm{CH}_{2}\right), 3.83(3 \mathrm{H}, s, \mathrm{OMe}), 3.90(3 \mathrm{H}, s, \mathrm{OMe}), 5.2(1 \mathrm{H}, b r \mathrm{~s}, \mathrm{OH})$, 6.73 and $6.86(2 \mathrm{H}, \mathrm{AB}-$ pattern, $J=8.3 \mathrm{~Hz}, \mathrm{H}-3$ and $\mathrm{H}-4), 6.81$ $(1 \mathrm{H}, d d, J=1.5 \mathrm{~Hz}, J=7.2 \mathrm{~Hz}, \mathrm{H}-11$ or $\mathrm{H}-13), 6.88(1 \mathrm{H}, d d, J$ $=1.5 \mathrm{~Hz}, J=8.4 \mathrm{~Hz}, \mathrm{H}-11$ or $\mathrm{H}-13), 7.25(1 \mathrm{H}, d d, J=7.2 \mathrm{~Hz}, J$ $=8.4 \mathrm{~Hz}, \mathrm{H}-12)$. The observed $\Delta \delta(\mathrm{OMe})$ was $0.075 \mathrm{GC} / \mathrm{MS} \mathrm{m} / \mathrm{z}$ (rel. int.): 314 (22), 313 (100), 298 (13), 296 (28), 282 (36), 270 (14), 257 (19), 256 (45), 255 (52), 241 (13), 239 (19), 225 (18), 223 (31), 165 (12), 152 (10), 71 (12).

Chemical shifts and differences in chemical shifts of methoxyl resonances, for $1: 1$ mixtures of dibenz $[d, f]$ azonine alkaloids. Natural mixture of 1 and $2: a, 3.78(3 \mathrm{H}), b, 3.84(3 \mathrm{H}), c, 3.90(6 \mathrm{H}), c$ $-b, 0.067, b-a, 0.057, c-a, 0.124 .1: a, 3.78(3 \mathrm{H})$ [C $-12 \mathrm{OMe}$, $b, 3.90(3 \mathrm{H})[\mathrm{C}-2 \mathrm{OMe}], b-a, 0.125$. Artificial mixture of 1 and 2: $a, 3.78(3 \mathrm{H})[\mathrm{C}-12 \mathrm{OMe} \mathrm{1}], b, 3.84(3 \mathrm{H})$ [C-11 OMe 2], $c, 3.90$ (6H) [C-2 OMe 1 + C-2OMe 2], $c-b, 0.068, b-a, 0.057, c-a$, 0.125. 1 and 9: $a, 3.78(3 \mathrm{H})$ [C-12 OMe 1], $b, 3.83(3 \mathrm{H})$ [C-10 OMe 9], $c, 3.90$ (6H) [C-2 OMe $1+\mathrm{C}-2$ OMe 9], $c \quad b, 0.075, b-a$, $0.050, c-a, 0.125$.

GC data. 1, a 0.68 , b $0.80 ; 2$, a 0.70, b $0.82 ; 3$, a 0.68 , b $0.82 ; 4$, a 0.71 , b $0.82 ; 6$, a 0.52 , b $0.62 ; 7$, a 0.95 , b $0.99 ; 9$, a 0.64 , b $0.80 ; 10$, a 1.19, b 1.23; Isolated mixture of natural alkaloids $1+2$, a 0.69 (broad), b 0.80 (sharp); artificial mixture of $1+2$, a 0.69 (broad) b 0.80 (sharp); $1+9$, a 0.64 and 0.68, b 0.80 (sharp).

TLC data. 1, a 0.83 , b 0.17 , c $0.10 ; 2$, a 0.83 , b 0.17 , c $0.10 ; 3$, a $0.85, \mathrm{~b} 0.22, \mathrm{c} 0.32 ; 4, \mathrm{a} 0.50, \mathrm{~b} 0.11, \mathrm{c} 0.01 ; 6, \mathrm{a} 0.83, \mathrm{~b} 0.35, \mathrm{c} 0.38 ; 7$, a 0.37 , b 0.07 , c $0.00 ; 9$, a 0.83, b 0.17, c $0.10 ; 10$, a 0.87 , b 0.17, c 0.23 ;
11 , a 0.51 , b 0.10 , c 0.01 .

Acknowledgements - Thanks are due to Dr. D. S. Bhakuni, Central Drug Research Institute, Lucknow, India, for a generous gift of natural laurifinine, and to Ir. E. Buurman, Diosynth B. V., Apeldoorn, The Netherlands, for supplying thebaine and $O$ methylflavinantine. We also thank Mr. E. J. Vlietstra and Dr. J. W. Zwikker, Organic Chemical Laboratory, State University of Utrecht, for preparation of the latter compound by electrochemical oxidation of laudanosine. The substance protostephanine, Lot 1848-65, was supplied by Dr. B. Pecherer of the Chemical Research Department of Hoffmann-La Roche Inc., Nutley, N.J. 07110, U.S.A. We are indebted to Professor Dr. A. R. Battersby, University Chemical Laboratory, Cambridge, England, for synthetic advice. Thanks are due to Miss G. F. La Vos and Ir. M. C. ten Noever de Brauw, Central Institute for Nutrition and Food Research, Zeist, The Netherlands, for capillary GC/MS measurements, and to Mr. C. Versluis and Dr. H. J. W. Spronck, Analytical Chemical Laboratory, State University of Utrecht, for recording GC/MS spectra. We are indebted to Mr. A. V. E. George, Drs. R. H. A. M. Janssen and Dr. H. W. A. Biessels, Organic Chemical Laboratory, State University of Utrecht, for recording ${ }^{1} \mathrm{H}$ NMR and performing shift experiments. Thanks are due to $\mathrm{Mr}$. P. Wijkens for synthetic help. The 'Arya II' plants, used in this research, were cultivated by Ir. W. J. M. Meyer, Agricultural University, Wageningen, The Netherlands. This work is part of the thesis by $\mathbf{H}$. G. Theuns (in preparation) and was initiated as a consultant to the United Nations Division of Narcotic Drugs.

\section{REFERENCES}

1. Küppers, F. J. E. M., Salemink, C. A., Bastart, M. and Paris, M. (1976) Phytochemistry 15, 444.

2. Phillipson, J. D., Handa, S. S. and El-Dabbas, S. W. (1976) Phytochemistry 15, 1297.

3. Hodges, C. C., Horn, J. S. and Rapoport, H. (1977) Phytochemistry 16, 1939.

4. Theuns, H. G., van Dam, J. E. G., Luteyn, J. M. and Salemink, C. A. (1977) Phytochemistry 16, 753.

5. Rönsch, H. and Schade, W. (1979) Phytochemistry 18, 1089.

6. Neubauer, D. and Mothes, K. (1963) Planta Med. 11, 387.

7. Theuns, H. G., Vlietstra, E. J. and Salemink, C. A. (1983) Phytochemistry 22, 247.

8. Uprety, H. and Bhakuni, D. S. (1975) Tetrahedron Letters 1201.

9. Pande, H. and Bhakuni, D. S. (1976) J. Chem. Soc. Perkin Trans. 1, 2197.

10. Bentley, K. W. (1967) J. Am. Chem. Soc. 89, 2464.

11. Channon, R. T., Kirby, G. W. and Massey, S. R. (1969) J. Chem. Soc. (D) 92.

12. Fales, H. M. and Warren, K. S. (1967) J. Org. Chem. 32, 501.

13. Lousberg, R. J. J. Ch., Paolillo, L., Kon, H. and Weiss, U. (1970) J. Chem. Soc. (C) 2154.

14. Ito, K., Tanaka, H. and Shibata, M. (1978) Heterocycles 9, 485.

15. Ito, K. and Tanaka, H. (1974) Chem. Pharm. Bull. 22, 2108.

16. Küppers, F. J. E. M., Lousberg, R. J. J. Ch., Bercht, C. A. L. and Salemink, C. A. (1974) United Nations Document ST/SOA/SER. J/8.

17. Kondo, H. and Takeda, K. (1958) Ann. Rep. Itsuu Lab. 9, 78.

18. Ito, K., Furukawa, H. and Tanaka, H. (1971) Chem. Pharm. Bull. 19, 1509.

19. Ito, K., Furukawa, H., Haruna, M. and Lu, S.-T. (1973) Yakugaku Zasshi 93, 1671. 
20. Ito, K., Furukawa, H., Haruna, M. and Ito, M. (1973) Yakugaku Zasshi 93, 1674.

21. Ito, K., Furukawa, H. and Haruna, M. (1973) Yakugaku Zasshi 93, 1611.

22. Ito, K., Haruna, M. and Furukawa, H. (1975) Yakugaku Zasshi 95, 358.

23. Ahmad, V. U., Najmus-Saqib, Q., Usmanghani, K. and Miana, G. A. (1980) Scientia Pharmaceutica 48, 169.

24. Kupchan, S. M. and Kim, C.-K. (1976) J. Org. Chem. 41, 3210.

25. Kupchan, S. M. and Kim, C.-K. (1975) J. Am. Chem. Soc. 97, 5623.

26. Kupchan, S. M., Kim, C.-K. and Lynn, J. T. (1976) J. Chem. Soc. Chem. Commun. 86.

27. Barton, D. H. R., Boar, R. B. and Widdowson, D. A. (1970) J. Chem. Soc. (C) 1213.
28. Bhakuni, D. S. and Singh, A. N. (1978) J. Chem. Soc. Perkin Trans. 1, 618.

29. Robinson, R. (1947-1948) Proc, R. Soc., B. 135, 14.

30. Thornber, C. W. (1969) Ph.D. Thesis (Liverpool, 1969).

31. Battersby, A. R., Bhatnagar, A. K., Hackett, P., Thornber, C. W. and Staunton, J. (1981) J. Chem. Soc. Perkin Trans. 1 2002.

32. Kupchan, S. M., Kim, C.-K. and Miyano, K. (1976) Heterocycles 4, 235.

33. Hazlet, S. E. and Brotherton, R. J. (1962) J. Org. Chem. 27, 3253.

34. Farkas, L., Sóti, F., Incze, M. and Nógradi, M. (1974) Chem. Ber. 107, 3874.

35. Späth, E., Orechoff, A. and Kuffmer, F. (1934) Chem. Ber. 67 , 1214. 